\section{Nutrient Uptake and Loss by Container-grown Deciduous and Evergreen Rhododendron Nursery Plants}

\author{
Carolyn F. Scagel ${ }^{1}$ \\ U.S. Department of Agriculture, Agricultural Research Service, Horticultural \\ Crops Research Unit, 3420 NW Orchard Avenue, Corvallis, OR 97330
}

\section{Guihong Bi}

Department of Plant and Soil Sciences, Truck Crops Branch Experiment Station, Mississippi State University, 2024 Experiment Station Road, Crystal Springs, MS 39059

\section{Leslie H. Fuchigami}

Department of Horticulture, Oregon State University, Corvallis, OR 97330

Richard P. Regan

Department of Horticulture, North Willamette Research and Extension Center, Oregon State University, Aurora, OR 97002

Additional index words. Rhododendron 'P.J.M.', Rhododendron 'English Roseum', Rhododendron 'Gibraltar', nursery container production, mineral nutrition

Abstract. The influence of nitrogen (N) fertilizer application on plant allocation, uptake, and demand for other essential nutrients was evaluated from May 2005 to Feb. 2006 in evergreen Rhododendron 'P.J.M. Compact' (PJM) and 'English Roseum' (ER) and deciduous Rhododendron 'Gibraltar' (AZ) grown in containers filled with soilless substrate. Net nutrient uptake and losses were calculated using piecewise regression and uptake efficiency, root absorption capacity, aboveground demand, nutrient use efficiency, and uptake ratios between $N$ and other nutrients ( $N$ ratios) were calculated using net uptake between harvest dates. Nitrogen application increased uptake rate of all nutrients, enhanced late-season uptake of many nutrients, and increased the rate of nutrient loss during the winter. Nutrient uptake often occurred as late as November in plants grown with $\mathbf{N}$ but was usually undetectable after September in plants grown without additional $\mathbf{N}$ fertilizer. Nutrient losses during the winter were not always associated with biomass loss and were related to differences in preferential nutrient allocation to different structures and the plant's ability to export nutrients before biomass loss. Plants with a greater potential for rapid growth were more capable of later-season nutrient uptake than plants with slower growth rates. Nitrogen availability altered $N$ ratios indicating that when adding $\mathrm{N}$ to container-grown Rhododendron, fertilizers with higher ratios of $\mathrm{N} / \mathrm{phosphorus}$ (PJM, AZ), N/calcium (PJM, ER), N/boron (PJM AZ), N/copper (PJM, ER), and N/iron (PJM, ER) and lower ratios of N/potassium (PJM, ER, AZ), N/sodium (PJM, ER, AZ), N/ calcium (AZ), N/boron (ER), N/manganese (AZ), and N/zinc (ER) may be needed to optimize growth and minimize nutrient inputs. Increasing $N$ availability altered uptake efficiency, root absorption capacity, aboveground demand, and nutrient use efficiency for several nutrients, indicating that changes in $\mathrm{N}$ management practices need to consider how altering $\mathbf{N}$ application rates may influence the plant's ability to take up and use other nutrients. This information can be used to develop fertilizer formulations to minimize excess application of nutrients and to evaluate the potential effects of altering $\mathbf{N}$ management practices on use of production resources. Our results indicate that nutrient management strategies for perennial crops such as Rhododendron need to take into consideration not only the nutrient demand for current growth, but also how to optimize nutrient availability for uptake that contributes to future growth potential and endproduct quality.

Container-grown nursery plants commonly exhibit low recovery of nutrients from fertilizer, suggesting nutrient management practices can be improved by understanding when and how plants most efficiently take up nutrients (Colangelo and Brand, 2001). Nutrient changes in bareroot nursery trees and container pro- from bareroot and forest tree nursery production systems to production of containergrown ornamental nursery plants.

Research on nutrient uptake by containergrown nursery plants has primarily focused on $\mathrm{N}$ because it is the most important nutrient for plant growth (Millard, 1996); and losses from production systems impact environmental quality (Alt, 1998). Plants require other nutrients in addition to $\mathrm{N}$ for vegetative and reproductive growth (Marschner, 1995). The balance between nutrients is almost as important as nutrient availability in limiting crop productivity or quality (Ingestad, 1991). Plant growth is restricted when not enough or too much of one or more nutrients is present, and excess applications of certain nutrients are potential sources of pollution to the environment (Huett, 1997). Changing the availability of one nutrient can affect plant uptake, transport, and demand for other nutrients (Epstein and Bloom, 2005; Scagel et al., 2008a, 2008b), and plants usually maintain a restricted balance among nutrients (Bazzaz, 1997; Chapin et al., 1987).

Fertilizer use in container nursery production can be decreased without sacrificing growth (Cabrera, 2004; Struve and Rose, 1998). One way to optimize nutrient management practices is to determine how $\mathrm{N}$ uptake by containergrown nursery plants is related to uptake of other nutrients. Understanding the relationships between uptake of different nutrients will aid in the development of fertilizer management strategies that increase fertilizer efficiency by synchronizing nutrient availability with nutrient demand and maintain stable internal nutrient ratios. This information is needed to assess the physiological consequences of plant nutrient composition and to determine what extent nutrient management practices and fertilizer formulation can be altered to balance acquisition and allocation of nutrients (Rytter et al., 2003).

Rhododendron cultivars have variable growth rates, morphological attributes, and growth habits (e.g., deciduous versus evergreen, lepidote versus elipidotes) that influence how they use $\mathrm{N}$ and other nutrients (Grelet et al., 2001; Scagel et al., 2008a, 2008b). Literature on $\mathrm{N}$ use in Rhododendron has focused on growth responses of bareroot nursery plants to different fertilizers (Witt, 1994) and $\mathrm{N}$ dynamics in natural systems (Lamaze et al., 2003; Pasche et al., 2002). Recent research has indicated that fall $\mathrm{N}$ uptake in 1-year-old container-grown Rhododendron balances $\mathrm{N}$ losses as a result of leaf abscission, root turnover, and dormant season maintenance functions (Bi et al., 2007a; Scagel et al., 2007). Additionally, although increasing $\mathrm{N}$ fertilizer application rate does not require a proportional increase in other nutrients to impact biomass of container-grown Rhododendron (Scagel et al., 2008a), lowering $\mathrm{N}$ rates can decrease the plant's ability to take up other nutrients.

Nitrogen uptake by container-grown Rhododendron can occur in the fall and loss of biomass by container-grown Rhododendron in the fall and winter can result in $\mathrm{N}$ loss (Bi et al., 2007a; Scagel et al., 2007). Scagel et al. (2008a) only described the relationship between $\mathrm{N}$ uptake and uptake of other nutrients 
between May and September by containergrown Rhododendron. The goal of the current study was to assess the effects of $\mathrm{N}$ availability on changes in nutrients other than $\mathrm{N}$ during the fall and winter in container-grown Rhododendron. Our objectives were to determine whether $\mathrm{N}$ availability alters 1 ) the uptake of other nutrients; 2) allocation of other nutrients among different plant structures; 3) ratios of $\mathrm{N}$ uptake to uptake of other nutrients ( $\mathrm{N}$ uptake ratios); and 4) nutrient losses during the fall and winter. To address these objectives, nutrient uptake and allocation in one deciduous and two evergreen cultivars of Rhododendron grown with different amounts of $\mathrm{N}$ were assessed from May through February.

\section{Materials and Methods}

The methods used in the present study are based on Scagel et al. (2007). Plants used in this experiment were 1-year-old liners of two evergreen cultivars, Rhododendron P.J.M. Compact [ARS\#874 (PJM)] and Rhododendron English Roseum [RHS\#58 (ER)], and one deciduous cultivar, Rhododendron Gibraltar [RHS\#58 (AZ)]. Plants were obtained from a commercial nursery as liner $\left(112-\mathrm{cm}^{3}\right.$ rooting volume) stock of clonally propagated tissue-cultured plants.

Plant culture, treatments, and harvests. Plants were transplanted on 25 Apr. 2005 into 3.8-L (1 gal) containers (GL-400; Nursery Supplies, Inc., McMinnville, OR) filled with a substrate of Douglas-fir bark, sphagnum peatmoss, perlite, vermiculite, dolomitic lime, gypsum (SB-300; Sun Gro Horticulture, Bellevue, WA) and were grown outdoors in Corvallis, OR (long. 45 $59^{\prime} 04^{\prime \prime} \mathrm{N}$, lat. $123^{\circ} 27^{\prime} 22^{\prime \prime} \mathrm{W}$ ). Forty plants of each cultivar were randomly assigned to one of two groups and fertilized twice a week from 29 Apr. to 2 Sept. 2005. At each application, one group (0N treatment) received $250 \mathrm{~mL}$ of $\mathrm{N}$-free fertilizer (1.06 mg. $\mathrm{mL}^{-1}$, Cornell No N Eq. 0-6-27; Greencare Fertilizers, Kankakee, IL), whereas the other ( $+\mathrm{N}$ treatment) received $250 \mathrm{~mL}$ of the $\mathrm{N}$-free fertilizer plus $140 \mathrm{mg} \cdot \mathrm{L}^{-1}$ of $\mathrm{N}\left(\mathrm{NH}_{4} \mathrm{NO}_{3}\right.$; Sigma Aldrich, St. Louis, MO). Plants were watered to container capacity twice a day ( $0800 \mathrm{HR}$ and $1530 \mathrm{HR}$ ) from 2 May to 30 Sept. 2005 using one drip emitter $\left(2 \mathrm{~L} \cdot \mathrm{h}^{-1}\right.$ flow rate;

Received for publication 1 Sept. 2010. Accepted for publication 19 Nov. 2010.

This work was funded, in part, by the American Rhododendron Society, the USDA-ARS, Northwest Center for Nursery Crop Research, and the Oregon State Agricultural Research Foundation.

We gratefully acknowledge the technical assistance of Jesse Mitchell, Ben Ervin, Rose Jepson, Summer Hendricks, Maryann Resendes, and Suean Ott. We also thank Monrovia Growers, Dayton, $\mathrm{OR}$, for plant material.

Mention of a trademark, proprietary product, or vendor does not constitute a guarantee or warranty of the product by the U.S. Dept. of Agriculture and does not imply its approval to the exclusion of other products or vendors that also may be suitable.

${ }^{1}$ To whom reprint requests should be addressed; e-mail Carolyn.Scagel@ars.usda.gov.
Netafim Co., Valley Stream, NY) per container. Concentrations of nitrate and ammonium in irrigation water were less than $28 \mathrm{mg} \cdot \mathrm{L}^{-1} \mathrm{NO}_{3}$ and $10 \mathrm{mg} \cdot \mathrm{L}^{-1} \mathrm{NH}_{4}$. Irrigation requirements were corrected weekly based on gravimetric determination of container capacity from $+\mathrm{N}$ plants of each cultivar. Five plants were harvested at transplanting for initial estimates of biomass and nutrient composition and approximately every 4 weeks from 18 July 2005 to 1 Feb. 2006. Shoots were cut at the soil surface, separated into leaves and stems, and divided into 1-year-old and 2-year-old structures, when applicable. Roots were removed from containers and washed of the substrate. Leaves, stems, and roots were dried at $65^{\circ} \mathrm{C}$ in a forcedair oven, weighed, ground, and analyzed for nutrient composition.

Nutrient analyses. Plant samples taken for nutrient analyses were analyzed for concentrations of $\mathrm{N}$ as described in Scagel et al. (2007) and concentrations of other macro- and micronutrients using inductively coupled plasmaoptical emission spectroscopy after digestion of a dried sample in nitric acid as described in Scagel et al. (2008a). Reference standard apple leaves (\#151, National Institute of Standards and Technology, Gaithersburg, MD) were run with samples for all procedures to ensure accuracy of results with $\pm 3 \% \mathrm{cv}$. Nutrient content of each structure was calculated by multiplying the concentration in each structure by the dry weight of each structure. Total plant content of each nutrient was calculated as the sum overall structures. Samples of the growing substrate were taken at the beginning of the experiment and analyzed for nutrient composition by standard methods (Berg and Gardner, 1979).

Statistical analyses. Containers were arranged in a completely randomized design with two rates of $N$ fertilizer $(0 N,+N)$, three cultivars (PJM, ER, AZ), eight harvest dates, and five replicates per treatment. All analyses were performed using the Statistica ${ }^{\circledR}$ statistical package (Statsoft, Inc., Tulsa, OK). Data were tested for homogeneity of variance (Levene's test) and normality (Kolmogorov-Smirnov test) and transformed if necessary. When transformation was necessary, back-transformed means and arithmetic sEs are presented in tables. Variables that required transformation are indicated in subsequent text. Biomass and $\mathrm{N}$ data from this study have previously been reported (Scagel et al., 2007) and are summarized in the "Results" section to show relationships to changes in nutrients other than $\mathrm{N}$.

Allocation of biomass and nutrients to different structures was estimated by calculating the proportion of total plant biomass and total nutrient content in different structures. Nutrient uptake efficiency was estimated by calculating maximum net uptake of a specific nutrient as a proportion of total nutrients available from the growing substrate and fertilizer. The influence of $\mathrm{N}$ availability on nutrient uptake efficiency and allocation of biomass and nutrients to each structure was assessed by analysis of variance using a complete factorial design with cultivar and $\mathrm{N}$ treatment at specific harvests [time (d) after transplanting] as main effects. Differences in nutrient uptake efficiency and allocation were determined using Tukey's honestly significant difference at $P<$ 0.05 and changes in allocation between different harvest dates were assessed using polynomial contrasts at $P<0.05$. Allocation data were arcsine-transformed before analyses and data for boron (B), copper $(\mathrm{Cu})$, and zinc $(\mathrm{Zn})$ uptake efficiency were log transformed before analyses. Back-transformed data are presented in tables.

The influence of $\mathrm{N}$ availability on rates of net biomass and nutrient accumulation was assessed using piecewise regression. In examining relationships between the independent variable (time) and a dependent variable (nutrient content or biomass), it was often apparent that a simple linear function was not appropriate for the entire range of values, but a nonlinear function might not fit best either. Over short ranges, a linear function can approximate any process (Guthrie et al., 2005; Toms and Lesperance, 2003); therefore, use of piecewise regression models was justified to define phases of whole plant nutrient dynamics using easy to interpret multiple linear functions. A two-function piecewise model with one breakpoint (c) was used to determine the most appropriate model for each nutrient over time as described by Shuai et al. (2003): $y=$ $\mathrm{m}_{1}+\mathrm{b}_{1}{ }^{*} \mathrm{x}$ for $\mathrm{x} \leq \mathrm{c}$ and $\mathrm{y}=\mathrm{m}_{2}+\mathrm{b}_{2} * \mathrm{x}$ for $\mathrm{x}>\mathrm{c}$; where $\mathrm{m}_{1}=$ shared $\mathrm{y}$-intercept between $\mathrm{N}$ treatments, $\mathrm{b}_{1}$ and $\mathrm{b}_{2}=$ slopes of the linear segments of the relationship before $\left(b_{1}\right)$ and after the breakpoint $\left(b^{2}\right), m_{2}=y$-intercept for the breakpoint, and $\mathrm{c}$ is the breakpoint. Procedures described by Schabenberger and Pierce (2002) were used for nonlinear model selection and comparison. Linear, curvilinear, and piecewise regression functions were compared using the lack-of-fit test to determine the most appropriate model with the smallest mean square error. Differences in regression coefficients between cultivars and $\mathrm{N}$ treatments were evaluated at $P<0.05$ and differences between breakpoints were evaluated and selected as in Piepho and Ogutu (2003).

Net biomass growth $\left(\mathrm{mg} \cdot \mathrm{d}^{-1}\right)$ and nutrient uptake $\left(\mathrm{mg} \cdot \mathrm{d}^{-1}\right)$ between specific harvests was calculated as the difference in total plant biomass and nutrient content, respectively, between harvests (Scagel et al., 2008a). These between-harvest rates were used to estimate uptake ratios $\left(\mathrm{N}\right.$ ratios; $\mathrm{mg} \cdot \mathrm{d}^{-1} \mathrm{~N}$ uptake per $\mathrm{mg} \cdot \mathrm{d}^{-1}$ nutrient uptake; Scagel et al., 2008a), nutrient use efficiency $\left(\mathrm{mg} \cdot \mathrm{d}^{-1}\right.$ biomass per $\mathrm{mg} \cdot \mathrm{d}^{-1}$ nutrient; Marschner, 1995; Milla et al., 2005), root absorption capacity $\left(\mathrm{mg} \cdot \mathrm{d}^{-1}\right.$ nutrient uptake per $\mathrm{g}$ root dry weight; Chapin, 1980), and aboveground demand $\left(\mathrm{mg} \cdot \mathrm{d}^{-1} \mathrm{nu}-\right.$ trient uptake per $g$ aboveground dry weight; Chapin, 1980) for each plant. The influence of $\mathrm{N}$ availability on $\mathrm{N}$ uptake ratios, nutrient use efficiency, root absorption capacity, and aboveground demand was evaluated by polynomial regression as described in Scagel et al. (2008a). Mallow's CP was used as the criterion for choosing the best subset of predictor effects and comparing parameters from regression functions of nutrient uptake versus $\mathrm{N}$ uptake ( $\mathrm{N}$ ratios), biomass growth versus nutrient uptake (nutrient use efficiency), root biomass 
versus nutrient uptake (root absorption capacity), and aboveground biomass versus nutrient uptake (aboveground demand).

When making inferences from any of our data we were conscious of our data being a snapshot in time showing only net accumulation or uptake and we regard our data as being a relative estimate of the parameters measured.

\section{Results and Discussion}

Biomass and nutrient accumulation in summer and fall. Nitrogen-fertilized plants $(+\mathrm{N}$ plants) accumulated more biomass and nutrients and continued to grow and accumulate nutrients longer into the fall and winter than plants grown without additional $\mathrm{N}$ in the growing substrate ( $0 \mathrm{~N}$ or $\mathrm{N}$-deficient plants) (Table 1). When plant growth is limited by $\mathrm{N}$ availability, demand for and uptake of other nutrients is expected to decline accordingly (Marschner, 1995), although not always in the same proportion (Scagel et al., 2008a).

Nitrogen application enhanced late-season uptake of most nutrients (Table 1). Late-season uptake of nutrients during the previous year can potentially increase nutrient reserves necessary for early new growth the next year. Perennial plants such as Rhododendron are highly dependent on $\mathrm{N}$ from reserves for initial new growth (Bi et al., 2007b; Grelet et al., 2003; Lamaze et al., 2003; Millard, 1996; Pasche et al., 2002). Nutrients other than $\mathrm{N}$ are also required for new growth and these nutrients may either come from reserves or from current season uptake. Nutrient uptake early in the growing season is often inefficient as a result of environmental factors such as low soil temperature or limited soil moisture (Karlsson, 1994; Lamaze et al., 2003; Pasche et al., 2002). Only late-season uptake of phosphorus (P) by $\mathrm{ER}$ and $\mathrm{AZ}$ was unaffected by $\mathrm{N}$ application in the present study, indicating factors other than $\mathrm{N}$ may influence the extent of $\mathrm{P}$ uptake (e.g., factors affecting availability of $\mathrm{P}$ in the growing substrate, root function, or mycorrhizal development) by these cultivars.

Plants in the different $\mathrm{N}$ treatments did not attain maximum net content of all nutrients at a similar time (Table 1). Differences in the timing of maximum content between nutrients may be related to seasonal changes in nutrient demand for specific plant functions. For example, $\mathrm{N}$ application did not influence calcium (Ca) until September. Plant accumulation of cations such as Ca commonly occurs in fall as a part of the process for developing coldhardiness (Raese and Curry, 2009). Plant demand for Ca may therefore be greatest in fall, in which case effects of $\mathrm{N}$ availability on $\mathrm{Ca}$ uptake may be more obvious in the fall and winter months. Similarly, the influence of N availability on manganese (Mn) uptake by PJM and ER was not observed until late fall or early winter. Manganese has essential roles in carbon and $\mathrm{NO}_{3}$ assimilation from photosynthesis and in protecting plants from oxidative stresses (Alscher et al., 2002; Marschner, 1995). Given the importance of Mn to leaf function, it is not surprising that $\mathrm{N}$ availability altered Mn uptake earlier in the deciduous cultivar AZ than the evergreen cultivars. Many evergreen plants photosynthesize during the winter when environmental conditions are conducive (Miyazawa and Kikuzawa, 2005).

Table 1. Net accumulation rate of biomass and nutrients, maximum biomass and content of nutrients, and timing when maximum biomass and nutrient content was attained by container-grown Rhododendron cultivars grown with $(+\mathrm{N})$ or without $(0 \mathrm{~N})$ additional nitrogen fertilizer.

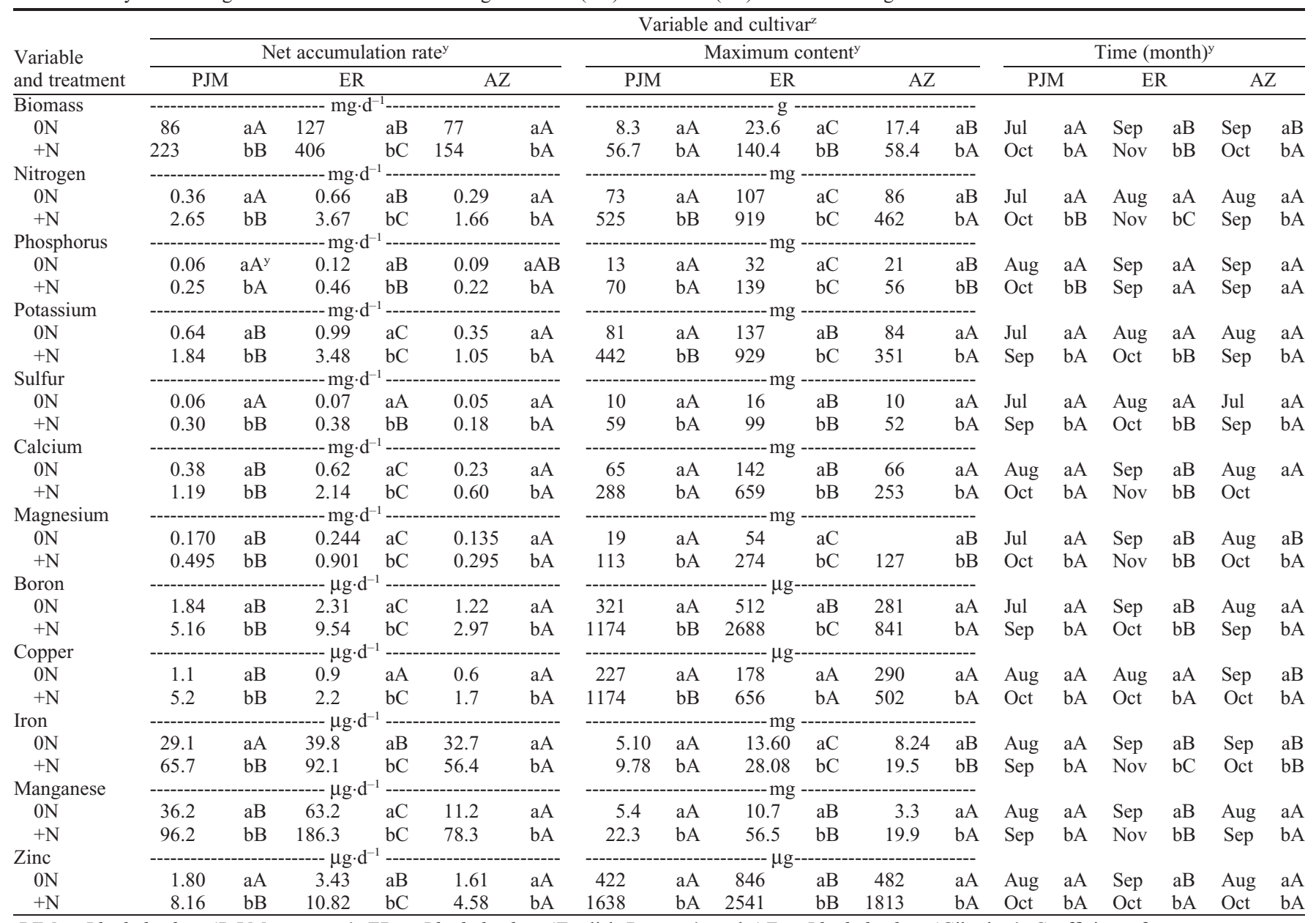

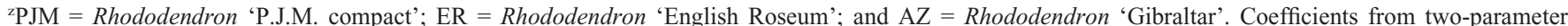
piecewise regression of biomass and content on time. Net accumulation rate estimated by the first slope $\left(b_{1}\right)$ between May 2005 and breakpoint when estimated maximum content was attained. Maximum content estimated by the Y-intercept for breakpoint. Time estimated by the X-intercept for breakpoint.

${ }^{\mathrm{y}}$ Values followed by different lower case letters within a column and variable denote significant $(P<0.05)$ differences in coefficients between nitrogen $(\mathrm{N})$ treatments within cultivars. Values followed by the different upper case letters within a row and variable denote significant differences in coefficients between cultivars within $\mathrm{N}$ treatments. 
Some Mn-containing enzymes are also associated with improved plant cold tolerance (Park and Chen, 2006); therefore, the effects of $\mathrm{N}$ availability on Mn uptake during the fall and winter may also influence the ability of plants to tolerate cold temperatures.

Differences in the rate and timing of net nutrient and biomass accumulation among cultivars (Table 1) may also be a result of differences in growth rate and leaf retention. Growth rate is one of the primary driving factors for nutrient uptake (Marschner, 1995) and can result in differences in demand for specific nutrients. For example, ER had greater rates of biomass accumulation and nutrient uptake and accumulated many of the nutrients later in the year than AZ and PJM, which resulted in higher content of most nutrients in ER than PJM and AZ. Likewise, when $\mathrm{N}$ was applied, PJM accumulated biomass and nutrients more rapidly than AZ. In our study, nutrient accumulation by only one of the two evergreen cultivars (ER) occurred later into fall than it did in the deciduous cultivar. Retention of photosynthetic structures may result in evergreen plants being more capable of nutrient uptake later in the year than deciduous plants (Kummerow, 1983). Considering potential nutrient losses from leaf senescence and root turnover, it is possible that nutrient uptake occurred later in the year than presented.

Synchronization between biomass and nutrient accumulation in summer and fall. Maximum net biomass was achieved before, in conjunction with, or after maximum net nutrient content was attained (Table 1). Maximum growth and content of $\mathrm{N}$ and magnesium $(\mathrm{Mg})$ in PJM; $\mathrm{Ca}, \mathrm{Mg}$, iron (Fe), and $\mathrm{Mn}$ in $\mathrm{ER}$; and $\mathrm{Cu}$ and $\mathrm{Fe}$ in $\mathrm{AZ}$ occurred concurrently in both $\mathrm{N}$ treatments. In $\mathrm{N}$-fertilized plants, maximum growth and uptake of $\mathrm{P}, \mathrm{Ca}, \mathrm{Cu}$, and $\mathrm{Zn}$ in PJM; $\mathrm{N}$ in ER; and $\mathrm{Ca}, \mathrm{Mg}$, and $\mathrm{Zn}$ in $\mathrm{AZ}$ also occurred concurrently. Synchronized timing of maximum biomass and nutrient content indicates a strong interrelationship between growth and nutrient uptake and potential regulation by similar factors, e.g., temperature effects on plant growth, nutrient availability in the growing substrate, and root physiological processes. Nutrient management strategies for these specific nutrients can be derived relative to nutrient demands for growth.

Nitrogen application altered the synchronization between growth (biomass) and nutrient uptake (content) of all nutrients except $\mathrm{N}$ and $\mathrm{Mg}$ in PJM; K, sulfur (S), $\mathrm{Ca}, \mathrm{Mg}, \mathrm{B}, \mathrm{Cu}, \mathrm{Fe}$, and $\mathrm{Mn}$ in $\mathrm{ER}$; and $\mathrm{N}$, potassium (K), S, B, Cu, $\mathrm{Fe}$, and $\mathrm{Mn}$ in AZ (Table 1). For certain nutrients $\mathrm{N}$ deficiency prolonged uptake of nutrients other than $\mathrm{N}$ after maximum net biomass was attained. For example N-deficient PJM accumulated $\mathrm{P}, \mathrm{Ca}, \mathrm{Cu}$, and $\mathrm{Zn}$ after maximum biomass was attained, whereas maximum biomass occurred in conjunction with maximum content of these nutrients in N-fertilized PJM. Any nutrient uptake that occurs after maximum biomass is attained indicates passive uptake, luxury consumption, or increased storage in support of next season's growth. When plants take up nutrients after net growth has stopped, nutrient management strategies for these specific nutrients need to consider nutrient demand based on growth and storage.

Supplying plants with adequate $\mathrm{N}$ resulted in net biomass accumulation after net

Table 2. Nitrogen (N) uptake ratios, nutrient uptake efficiency, and net loss of nutrients by container-grown Rhododendron cultivars grown with $(+\mathrm{N})$ or without $(0 \mathrm{~N})$ additional nitrogen fertilizer between May 2005 and Feb. 2006.

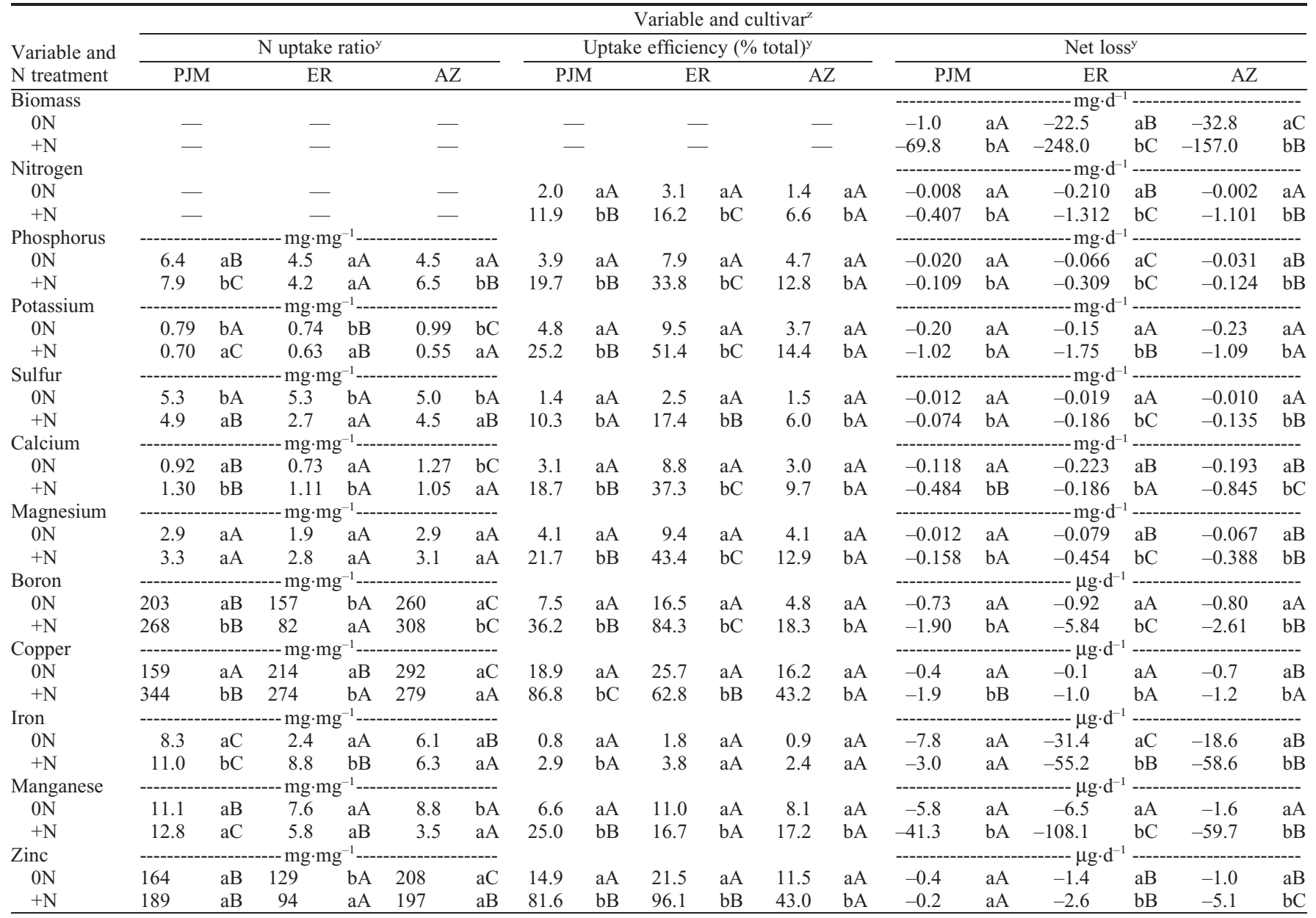

${ }^{2} \mathrm{PJM}=$ Rhododendron 'P.J.M. compact'; $\mathrm{ER}=$ Rhododendron 'English Roseum'; and $\mathrm{AZ}=$ Rhododendron 'Gibraltar'. N uptake ratio: coefficients from linear regression of $\mathrm{N}$ uptake on uptake of nutrients other than $\mathrm{N}$ estimating the $\mathrm{N}$ uptake ratio from the slope (b). Uptake efficiency: maximum net uptake as a proportion of total nutrients available from growing substrate and fertilizer. Net loss: coefficients from two-parameter piecewise regression of biomass and content on time estimating the rate of nutrient loss from the second slope $\left(b_{2}\right)$ between the breakpoint when estimated maximum content was attained and Feb. 2006.

${ }^{y}$ Values followed by different lower case letters within a column and variable denote significant $(P<0.05)$ differences in intercepts and coefficients between $\mathrm{N}$ treatments within cultivars. Values followed by the different upper case letters within a row and variable denote significant differences in intercepts and coefficients between cultivars within $\mathrm{N}$ treatments. 
accumulation of certain nutrients was attained (Table 1). For example, N-fertilized PJM accumulated biomass after maximum $\mathrm{K}, \mathrm{S}, \mathrm{B}, \mathrm{Fe}$, and $\mathrm{Mn}$ content was attained; ER accumulated biomass after maximum $\mathrm{P}, \mathrm{K}, \mathrm{S}, \mathrm{B}, \mathrm{Cu}$, and $\mathrm{Zn}$ content was attained, and $\mathrm{AZ}$ accumulated biomass after maximum $\mathrm{N}, \mathrm{P}, \mathrm{K}, \mathrm{S}, \mathrm{B}$, and $\mathrm{Mn}$ content was attained. When maximum biomass was attained after maximum nutrient content, nutrient uptake and growth in the fall may be interrelated but might not be regulated by similar factors. When plants cease net nutrient accumulation before net biomass accumulation, nutrient management strategies for these specific nutrients need to consider nutrient demand based on factors other than just growth.

Strong positive relationships between plant growth and nutrient uptake are commonly reported for annual plants (Rodgers and Barneix, 2006). These strong relationships allow for nutrient management strategies for production of annual crops to be derived relative to a nutrient demand based on growth rate. The relationships between nutrient uptake and growth in woody plants are complicated by their perennial growth habit and their need to conserve nutrients between growing seasons (Aerts and Chapin, 2000). Additionally, pulses of nutrient availability characterize many seasonal environments and can result in strong asynchrony between nutrient uptake and plant demand (Chapin et al., 1990). Our results indicate that nutrient management strategies for Rhododendron should consider the nutrient demand for the current season's growth and optimize nutrients for uptake that contributes to future growth and end-product quality.

Nitrogen ratios. Cultivars evaluated had similar $\mathrm{N}$ ratios for certain nutrients when $\mathrm{N}$ was not limiting to growth (Table 2). For example, when $\mathrm{N}$ was not limiting to growth, $\mathrm{N} /$ $\mathrm{S}, \mathrm{N} / \mathrm{Ca}, \mathrm{N} / \mathrm{Mg}, \mathrm{N} / \mathrm{Cu}$, and N/Zn uptake ratios were similar between at least two of the three cultivars. This indicates that fertilizers with similar availability ratios for these nutrients in relationship to $\mathrm{N}$ will meet requirements of these different cultivars. In contrast, there were differences in $\mathrm{N}$ ratios among cultivars for certain nutrients. These differences indicate that fertilizer availability ratios for these nutrients, in relationship to N, could be altered for optimal growth of each cultivar. For example, regardless of $\mathrm{N}$ availability, optimum growth of ER may require fertilizer that maintains a lower ratio of $\mathrm{N}$ to most other nutrients in the growing substrate than either PJM or AZ. However, when $\mathrm{N}$ is not limiting, PJM may require fertilizer that maintains higher $\mathrm{N} /$ $\mathrm{P}, \mathrm{N} / \mathrm{K}, \mathrm{N} / \mathrm{Ca}, \mathrm{N} / \mathrm{Cu}, \mathrm{N} / \mathrm{Fe}$, and N/Mn availability ratios than $\mathrm{AZ}$.

Nitrogen application increased, decreased, or had no influence on $\mathrm{N}$ ratios (Table 2). The $\mathrm{N}$ ratios reflect the range in nutrient demand for plants grown in $\mathrm{N}$-deficient and $\mathrm{N}$-sufficient conditions (Scagel et al., 2008a). The uptake ratios of N/Mg, N/Mn, and N/Zn for PJM; N/P, $\mathrm{N} / \mathrm{Mg}$, and N/Mn for ER; and N/Mg, N/Cu, $\mathrm{N} / \mathrm{Fe}$, and $\mathrm{N} / \mathrm{Zn}$ for $\mathrm{AZ}$ were relatively stable regardless of $\mathrm{N}$ availability. This indicates that fertilizer formulations for these nutrients probably do not need to be altered with increasing or decreasing $\mathrm{N}$ application rates. Nitrogen application increased N/P, N/Ca, N/B, N/Cu, and $\mathrm{N} / \mathrm{Fe}$ uptake ratios in $\mathrm{PJM} ; \mathrm{N} / \mathrm{Ca}, \mathrm{N} / \mathrm{Cu}$, and $\mathrm{N} / \mathrm{Fe}$ uptake ratios in ER; and N/P and N/ $\mathrm{B}$ uptake ratios in AZ. This indicates that increased $\mathrm{N}$ rates may require fertilizer formulations with more of these nutrients, in relationship to $\mathrm{N}$, to optimize growth. In contrast, $\mathrm{N}$ application decreased $\mathrm{N} / \mathrm{K}$ and $\mathrm{N} / \mathrm{S}$ uptake ratios in $\mathrm{PJM} ; \mathrm{N} / \mathrm{K}, \mathrm{N} / \mathrm{S}, \mathrm{N} / \mathrm{B}$, and $\mathrm{N} / \mathrm{Zn}$ uptake ratios in ER; and N/K, N/S, N/Ca, and $\mathrm{N} / \mathrm{Mn}$ uptake ratios in AZ. This indicates that

Table 3. Root absorption capacity, whole plant nutrient use efficiency, and aboveground nutrient demand of container-grown Rhododendron cultivars grown with $(+N)$ or without $(0 N)$ additional nitrogen $(N)$ fertilizer between May 2005 and when plants attained maximum nutrient content.

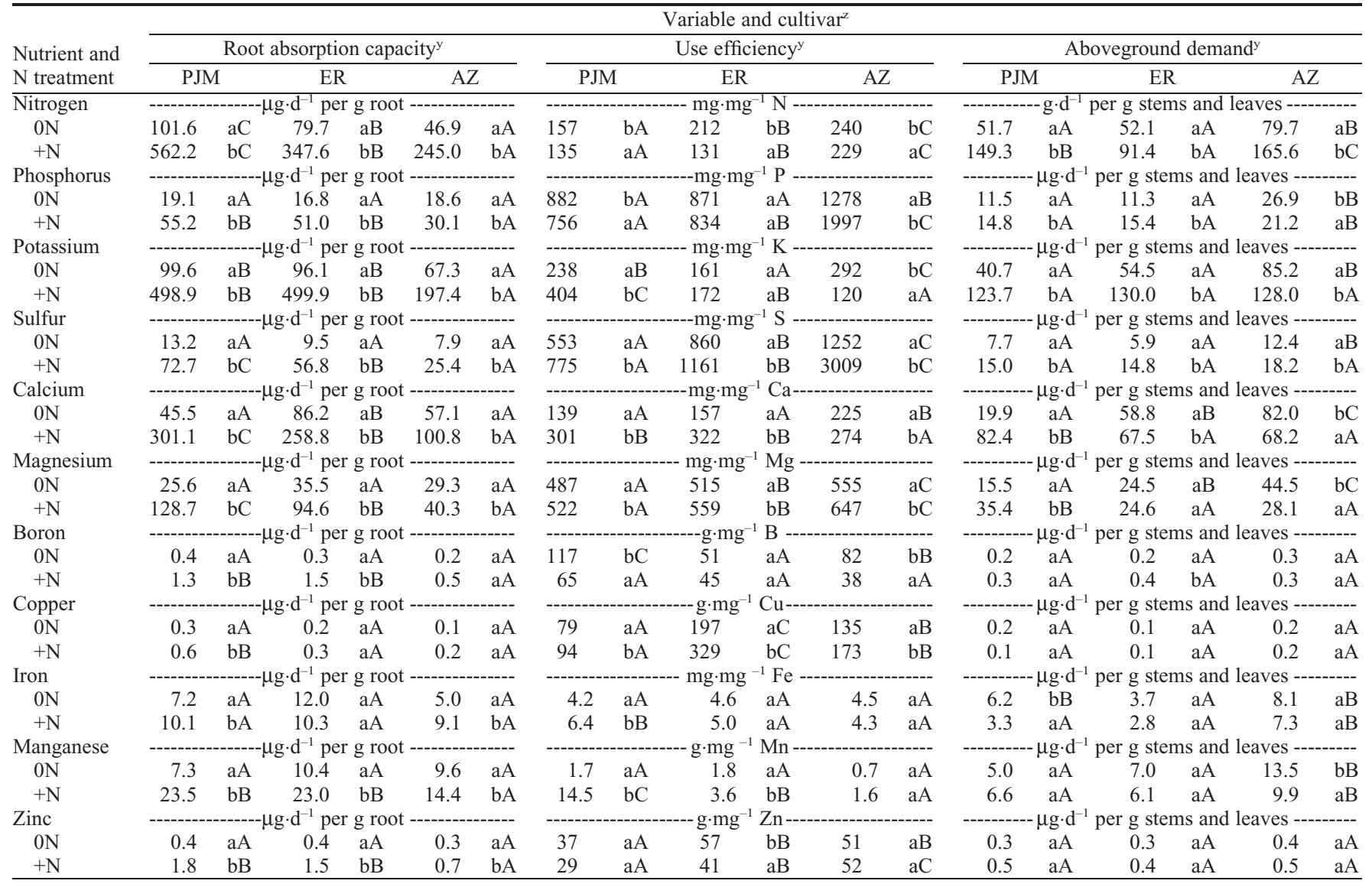

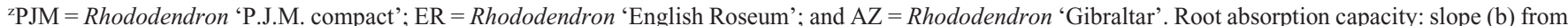
linear regression of nutrient uptake rate on dry weight of roots. Use efficiency: slope (b) from linear regression rate of biomass accumulation on nutrient uptake rate. Aboveground demand: slope (b) from linear regression of nutrient uptake rate on dry weight of stems and leaves.

${ }^{\mathrm{y}}$ Values followed by different lower case letters within a column and variable denote significant $(P<0.05)$ differences in intercepts and coefficients between $\mathrm{N}$ treatments within cultivars. Values followed by the different upper case letters within a row and variable denote significant differences in coefficients between cultivars within $\mathrm{N}$ treatments. 
increased $\mathrm{N}$ rates may therefore reduce need for these nutrients, in relationship to $\mathrm{N}$, and their potential production and environmental costs.

Information on plant response to different nutrient ratios in fertilizers can be found for many species; however, our current understanding of how this relates to variation in nutrient composition is limited (Ingestad, 1991; Ohlson and Staaland, 2001). This is primarily because nutrient ratios in fertilizers do not readily translate into nutrient availability in the growing substrate, particularly when controlled-release fertilizers are used. For common species produced in nurseries, including Rhododendron, little published information exists about how nutrient ratios in a plant change through time as a result of variation in uptake between different nutrients (Méndez and Karlsson, 2004). Our previous research (Scagel et al., 2008a) reported that increases in $\mathrm{N}$ uptake were not always associated with proportional increases in uptake of other nutrients between May and September by containergrown Rhododendron. The results from our present study indicate $\mathrm{N}$ ratios may also change during the fall and winter and may be useful for developing guidelines that improve fertilizer efficiency for all nutrients.
Nutrient uptake efficiency. Nitrogen application increased uptake efficiency of most nutrients (Table 2). This suggests that decreasing $\mathrm{N}$ availability in the growing substrate may reduce a plant's ability to take up nutrients other than $\mathrm{N}$ and has the potential to cause deficiencies in these nutrients. Nitrogen deficiency has been associated with $\mathrm{P}, \mathrm{K}, \mathrm{S}, \mathrm{Ca}, \mathrm{Mg}$, and $\mathrm{Mn}$ deficiency in Rhododendron (Scagel et al., 2008a).

There was no difference in uptake efficiency between cultivars when no $\mathrm{N}$ was applied (Table 2). However, when $\mathrm{N}$ was applied, ER had similar or higher uptake efficiency than PJM for all nutrients except $\mathrm{Cu}$ and Mn. Additionally, AZ had similar or lower uptake efficiency than PJM and ER for all nutrients. Nutrient uptake efficiency can be used to understand the potential for different cultivars to fully use the nutrients available to them during production and help in selection of cultivar-specific fertilizer formulations that minimize excess application of nutrients. For example, when $\mathrm{N}$ is not limiting growth, ER may be more efficient at using fertilizers containing less $\mathrm{N}, \mathrm{P}, \mathrm{K}, \mathrm{S}, \mathrm{Ca}, \mathrm{Mg}, \mathrm{B}$, and $\mathrm{Zn}$ than both PJM and AZ, and PJM may be able to grow with fertilizers containing less $\mathrm{Cu}$ and $\mathrm{Mn}$ than ER or AZ.
Root absorption capacity. Nitrogen application increased root absorption capacity for all nutrients in PJM, all nutrients except $\mathrm{Cu}$ and $\mathrm{Fe}$ in $\mathrm{ER}$, and all nutrients except $\mathrm{B}$ and $\mathrm{Cu}$ in $\mathrm{AZ}$ (Table 3). Nitrogen deficiency decreased both uptake efficiency and root absorption capacity for $\mathrm{N}, \mathrm{P}, \mathrm{K}, \mathrm{S}, \mathrm{Ca}, \mathrm{Mg}, \mathrm{Mn}$, and $\mathrm{Zn}$ for all cultivars. Decreased uptake efficiency and root absorption capacity indicates that $\mathrm{N}$ availability directly influenced root function in relationship to uptake of these nutrients. In contrast, $\mathrm{N}$ deficiency decreased the efficiency of $\mathrm{B}$ and $\mathrm{Cu}$ uptake in $\mathrm{AZ}$ and $\mathrm{Cu}$ uptake in ER and had no influence on root absorption capacity for these nutrients. This suggests the effects of $\mathrm{N}$ availability on uptake of these nutrients are not directly related to the ability of roots to absorb these nutrients but instead may be related to other factors such as root system size or nutrient availability in the growing substrate.

The rate of nutrient absorption by a root depends on nutrient supply to the root surface and the ability of the root to take up the nutrient (Chapin, 1980). Nitrogen-fertilized AZ generally had both lower root absorption capacity and lower nutrient uptake efficiency than PJM and ER (Table 3). If nutrient uptake efficiency is regulated by the capacity of roots

Table 4. Allocation (percentage of total) of biomass and nutrients to roots in Oct. 2005, Nov. 2005, and Feb. 2006 by three cultivars of container-grown Rhododendron grown with $(+\mathrm{N})$ or without $(0 \mathrm{~N})$ additional nitrogen $(\mathrm{N})$ fertilizer between May 2005 and Feb. 2006.

\begin{tabular}{|c|c|c|c|c|c|c|c|c|c|c|c|c|c|c|c|c|c|c|c|c|c|}
\hline \multirow{4}{*}{$\begin{array}{l}\text { Variable and } \\
\mathrm{N} \text { treatment } \\
\text { Biomass }\end{array}$} & \multicolumn{18}{|c|}{ Cultivar ${ }^{z}$ and time (months) } & & & \\
\hline & \multicolumn{6}{|c|}{$\mathrm{PJM}^{\mathrm{x}}$} & \multicolumn{6}{|c|}{$\mathrm{ER}^{\mathrm{x}}$} & \multicolumn{6}{|c|}{$A Z^{x}$} & \multicolumn{3}{|c|}{ Contrasts $^{\mathrm{y}}$} \\
\hline & \multicolumn{2}{|c|}{ Oct. } & \multicolumn{2}{|c|}{ Nov. } & \multicolumn{2}{|c|}{ Feb. } & \multicolumn{2}{|c|}{ Oct. } & \multicolumn{2}{|c|}{ Nov. } & \multicolumn{2}{|c|}{ Feb. } & \multicolumn{2}{|c|}{ Oct. } & \multicolumn{2}{|c|}{ Nov. } & \multicolumn{2}{|c|}{ Feb. } & \multirow[t]{2}{*}{ PJM } & \multirow[t]{2}{*}{ ER } & \multirow[t]{2}{*}{$\mathrm{AZ}$} \\
\hline & & & & & & & & & & & & & & & & & & & & & \\
\hline $0 \mathrm{~N}$ & 53 & $\mathrm{~b}$ & 57 & $\mathrm{~b}$ & 49 & $\mathrm{a}$ & 48 & $\mathrm{~b}$ & 59 & $\mathrm{~b}$ & 46 & $\mathrm{~b}$ & 65 & $\mathrm{~b}$ & 79 & $\mathrm{~b}$ & 80 & $\mathrm{~b}$ & NS & $Q$ & $L$ \\
\hline$+\mathrm{N}$ & 28 & $\mathrm{a}$ & 33 & $\mathrm{a}$ & 43 & $\mathrm{a}$ & 19 & $\mathrm{a}$ & 24 & $\mathrm{a}$ & 22 & $\mathrm{a}$ & 48 & $\mathrm{a}$ & 55 & $\mathrm{a}$ & 66 & $\mathrm{a}$ & $L$ & NS & $L$ \\
\hline \multicolumn{22}{|l|}{ Nitrogen } \\
\hline $0 \mathrm{~N}$ & 43 & $\mathrm{~b}$ & 46 & $\mathrm{~b}$ & 40 & $\mathrm{a}$ & 37 & $\mathrm{~b}$ & 47 & $\mathrm{~b}$ & 34 & $\mathrm{~b}$ & 50 & $\mathrm{~b}$ & 73 & $\mathrm{~b}$ & 76 & $\mathrm{~b}$ & NS & $Q$ & $L$ \\
\hline$+\mathrm{N}$ & 22 & $\mathrm{a}$ & 25 & $\mathrm{a}$ & 35 & $\mathrm{a}$ & 14 & $\mathrm{a}$ & 17 & $\mathrm{a}$ & 16 & $\mathrm{a}$ & 37 & $\mathrm{a}$ & 42 & $\mathrm{a}$ & 62 & $\mathrm{a}$ & $L$ & NS & $L$ \\
\hline Phosphorus & & & & & & & & & & & & & & & & & & & & & \\
\hline $0 \mathrm{~N}$ & 53 & $\mathrm{~b}$ & 55 & $\mathrm{~b}$ & 50 & $\mathrm{a}$ & 49 & $\mathrm{~b}$ & 63 & $\mathrm{~b}$ & 53 & $\mathrm{~b}$ & 68 & $\mathrm{~b}$ & 82 & $\mathrm{~b}$ & 83 & $\mathrm{~b}$ & NS & $Q$ & $L$ \\
\hline$+\mathrm{N}$ & 31 & $\mathrm{a}$ & 30 & $\mathrm{a}$ & 43 & $\mathrm{a}$ & 18 & $\mathrm{a}$ & 23 & $\mathrm{a}$ & 29 & $\mathrm{a}$ & 55 & $\mathrm{a}$ & 56 & $\mathrm{a}$ & 65 & $\mathrm{a}$ & $L$ & NS & $L$ \\
\hline Potassium & & & & & & & & & & & & & & & & & & & & & \\
\hline $0 \mathrm{~N}$ & 32 & $\mathrm{~b}$ & 46 & $\mathrm{~b}$ & 41 & $\mathrm{e}$ & 29 & $\mathrm{~b}$ & 42 & $\mathrm{~b}$ & 30 & $\mathrm{~b}$ & 44 & $\mathrm{~b}$ & 72 & $\mathrm{~b}$ & 79 & $\mathrm{~b}$ & $L, Q$ & $Q$ & $L$ \\
\hline$+\mathrm{N}$ & 12 & $\mathrm{a}$ & 15 & $\mathrm{a}$ & 25 & $\mathrm{a}$ & 10 & $\mathrm{a}$ & 13 & $\mathrm{a}$ & 12 & $\mathrm{a}$ & 33 & $\mathrm{a}$ & 30 & $\mathrm{a}$ & 63 & $\mathrm{a}$ & $L$ & NS & $L$ \\
\hline Sulfur & & & & & & & & & & & & & & & & & & & & & \\
\hline $0 \mathrm{~N}$ & 60 & $\mathrm{~b}$ & 51 & $\mathrm{~b}$ & 54 & $\mathrm{~b}$ & 50 & $\mathrm{~b}$ & 61 & $\mathrm{~b}$ & 43 & $\mathrm{~b}$ & 63 & $\mathrm{~b}$ & 77 & $\mathrm{~b}$ & 89 & $\mathrm{~b}$ & NS & $L, Q$ & $L$ \\
\hline$+\mathrm{N}$ & 32 & $\mathrm{a}$ & 29 & $\mathrm{a}$ & 43 & $\mathrm{a}$ & 15 & $\mathrm{a}$ & 29 & $\mathrm{a}$ & 23 & $\mathrm{a}$ & 54 & $\mathrm{a}$ & 59 & $\mathrm{a}$ & 77 & $\mathrm{a}$ & $L$ & $L, Q$ & $L$ \\
\hline Calcium & & & & & & & & & & & & & & & & & & & & & \\
\hline $0 \mathrm{~N}$ & 37 & $\mathrm{~b}$ & 42 & $\mathrm{~b}$ & 34 & $\mathrm{~b}$ & 33 & $\mathrm{~b}$ & 37 & $\mathrm{~b}$ & 23 & $\mathrm{~b}$ & 45 & $\mathrm{~b}$ & 65 & $\mathrm{~b}$ & 73 & $\mathrm{~b}$ & $Q$ & $L, Q$ & $L$ \\
\hline$+\mathrm{N}$ & 18 & $\mathrm{a}$ & 19 & $\mathrm{a}$ & 23 & $\mathrm{a}$ & 11 & $\mathrm{a}$ & 12 & $\mathrm{a}$ & 11 & $\mathrm{a}$ & 33 & $\mathrm{a}$ & 30 & $\mathrm{a}$ & 50 & $\mathrm{a}$ & $L$ & $\mathrm{NS}$ & $L$ \\
\hline Magnesium & & & & & & & & & & & & & & & & & & & & & \\
\hline $0 \mathrm{~N}$ & 47 & $\mathrm{~b}$ & 51 & $\mathrm{~b}$ & 47 & $\mathrm{~b}$ & 40 & $\mathrm{~b}$ & 47 & $\mathrm{~b}$ & 33 & $\mathrm{~b}$ & 59 & $\mathrm{~b}$ & 74 & $\mathrm{~b}$ & 80 & $\mathrm{~b}$ & NS & $L, Q$ & $L$ \\
\hline$+\mathrm{N}$ & 24 & $\mathrm{a}$ & 28 & $\mathrm{a}$ & 37 & $\mathrm{a}$ & 14 & $\mathrm{a}$ & 16 & $\mathrm{a}$ & 16 & $\mathrm{a}$ & 43 & $\mathrm{a}$ & 44 & $\mathrm{a}$ & 62 & $\mathrm{a}$ & $L$ & NS & $L$ \\
\hline Boron & & & & & & & & & & & & & & & & & & & & & \\
\hline $0 \mathrm{~N}$ & 23 & $\mathrm{~b}$ & 26 & $\mathrm{~b}$ & 22 & $\mathrm{a}$ & 23 & $\mathrm{~b}$ & 26 & $b$ & 16 & $\mathrm{~b}$ & 37 & $\mathrm{~b}$ & 64 & $\mathrm{~b}$ & 62 & $\mathrm{~b}$ & NS & $L$ & $L$ \\
\hline$+\mathrm{N}$ & 11 & $\mathrm{a}$ & 14 & $\mathrm{a}$ & 21 & $\mathrm{a}$ & 6 & $\mathrm{a}$ & 9 & $\mathrm{a}$ & 9 & $\mathrm{a}$ & 30 & $\mathrm{a}$ & 30 & $\mathrm{a}$ & 46 & $\mathrm{a}$ & $L$ & NS & $L$ \\
\hline Copper & & & & & & & & & & & & & & & & & & & & & \\
\hline $0 \mathrm{~N}$ & 83 & $\mathrm{~b}$ & 81 & $\mathrm{~b}$ & 82 & $\mathrm{a}$ & 82 & $\mathrm{~b}$ & 85 & $b$ & 88 & $\mathrm{~b}$ & 85 & $\mathrm{~b}$ & 90 & $\mathrm{~b}$ & 90 & $\mathrm{~b}$ & NS & NS & NS \\
\hline$+\mathrm{N}$ & 69 & $\mathrm{a}$ & 70 & $\mathrm{a}$ & 81 & $\mathrm{a}$ & 44 & $\mathrm{a}$ & 62 & $\mathrm{a}$ & 67 & $\mathrm{a}$ & 77 & $\mathrm{a}$ & 74 & $\mathrm{a}$ & 80 & $\mathrm{a}$ & $L$ & $L$ & NS \\
\hline Iron & & & & & & & & & & & & & & & & & & & & & \\
\hline $0 \mathrm{~N}$ & 85 & $\mathrm{~b}$ & 88 & $\mathrm{~b}$ & 87 & $\mathrm{~b}$ & 87 & $\mathrm{~b}$ & 82 & $\mathrm{~b}$ & 81 & $\mathrm{~b}$ & 88 & $\mathrm{~b}$ & 93 & $\mathrm{~b}$ & 94 & $\mathrm{~b}$ & NS & NS & NS \\
\hline$+\mathrm{N}$ & 67 & $\mathrm{a}$ & 77 & $\mathrm{a}$ & 77 & $\mathrm{a}$ & 65 & $\mathrm{a}$ & 68 & $\mathrm{a}$ & 68 & $\mathrm{a}$ & 79 & $\mathrm{a}$ & 81 & $\mathrm{a}$ & 84 & $\mathrm{a}$ & $L$ & NS & NS \\
\hline Manganese & & & & & & & & & & & & & & & & & & & & & \\
\hline $0 \mathrm{~N}$ & 34 & $\mathrm{~b}$ & 36 & $\mathrm{~b}$ & 35 & $\mathrm{a}$ & 36 & $\mathrm{~b}$ & 37 & $\mathrm{~b}$ & 29 & $\mathrm{~b}$ & 49 & $\mathrm{~b}$ & 58 & $\mathrm{~b}$ & 62 & $\mathrm{~b}$ & NS & $L$ & $L$ \\
\hline$+\mathrm{N}$ & 16 & $\mathrm{a}$ & 22 & $\mathrm{a}$ & 36 & $\mathrm{a}$ & 11 & $\mathrm{a}$ & 11 & $\mathrm{a}$ & 13 & $\mathrm{a}$ & 37 & $\mathrm{a}$ & 23 & $\mathrm{a}$ & 40 & $\mathrm{a}$ & $L$ & NS & $Q$ \\
\hline Zinc & & & & & & & & & & & & & & & & & & & & & \\
\hline $0 \mathrm{~N}$ & 76 & $\mathrm{~b}$ & 78 & $\mathrm{~b}$ & 78 & $\mathrm{~b}$ & 63 & $\mathrm{~b}$ & 68 & $\mathrm{~b}$ & 55 & $\mathrm{a}$ & 68 & $\mathrm{~b}$ & 76 & $\mathrm{~b}$ & 74 & $\mathrm{~b}$ & NS & $L, Q$ & $L$ \\
\hline$+\mathrm{N}$ & 53 & $\mathrm{a}$ & 58 & $\mathrm{a}$ & 67 & $\mathrm{a}$ & 43 & $\mathrm{a}$ & 50 & $\mathrm{a}$ & 53 & $\mathrm{a}$ & 60 & $\mathrm{a}$ & 59 & $\mathrm{a}$ & 53 & $\mathrm{a}$ & $L$ & $L$ & $L$ \\
\hline
\end{tabular}

"PJM = Rhododendron 'P.J.M. compact'; ER = Rhododendron 'English Roseum', and AZ = Rhododendron 'Gibraltar'.

${ }^{y}$ Non-significant $(\mathrm{NS})$ and significant $(P<0.05)$ linear $(L)$ and quadratic $(Q)$ response of allocation between dates for each cultivar within an N treatment.

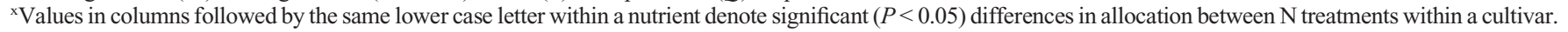


to take up nutrients, then plants with the lowest values of root absorption capacity will have the lowest nutrient uptake efficiency. Thus, nutrient uptake efficiency of AZ may be regulated primarily by root absorption capacity, and loss of roots or root function on AZ may have a greater impact on nutrient uptake of AZ than PJM and ER. In comparison, $\mathrm{N}$-fertilized ER had lower absorption capacity for N, S, Ca, and $\mathrm{Mg}$ than PJM but had higher uptake efficiency for these nutrients than PJM. Uptake efficiency for these nutrients by ER is, therefore, not fully accounted for by root absorption capacity, and uptake efficiency may be more influenced by factors affecting root growth and root function (e.g., root damage, pruning) than PJM.

Aboveground environmental conditions leading to rapid biomass accumulation can result in a high root absorption capacity (Chapin, 1980). In our study, root absorption capacity was not always a function of rate of biomass accumulation. Plants of AZ accumulated biomass more slowly than PJM and ER; therefore, it was not surprising that AZ had the lowest root absorption capacity. However, ER accumulated biomass more rapidly than PJM, and ER had a lower root absorption capacity than PJM. Plants of ER had much larger root systems than PJM (Scagel et al., 2007). Taken together, these results indicate differences in nutrient uptake between PJM and ER are related to both root system size (total root biomass) and function (per unit root biomass).

Aboveground nutrient demand. Nitrogen application increased aboveground demand for $\mathrm{N}, \mathrm{K}$, and $\mathrm{S}$ in all cultivars; increased aboveground demand for $\mathrm{P}, \mathrm{Ca}$, and $\mathrm{Mg}$ in PJM; increased aboveground demand for $\mathrm{P}$, $\mathrm{Ca}$, and $\mathrm{B}$ in ER; and decreased aboveground demand for $\mathrm{P}, \mathrm{Ca}, \mathrm{Mg}$, and $\mathrm{Mn}$ in $\mathrm{AZ}$ (Table 3). Nitrogen application increased both aboveground demand and root absorption capacity for $\mathrm{N}, \mathrm{P}, \mathrm{K}, \mathrm{S}, \mathrm{Ca}$, and $\mathrm{Mn}$ in PJM and $\mathrm{N}, \mathrm{P}, \mathrm{K}$, $\mathrm{S}, \mathrm{Ca}$, and $\mathrm{B}$ in ER. Increased aboveground demand and root absorption capacity indicates that aboveground growth and function was a primary driver for root uptake of these nutrients. In contrast, $\mathrm{N}$ application decreased aboveground demand and increased root absorption capacity for Fe in PJM and P, Ca, Mg, and $\mathrm{Mn}$ in $\mathrm{AZ}$. This suggests that $\mathrm{N}$ deficiency increases the aboveground demand for these nutrients; additionally, it indicates that when plants are grown with adequate $\mathrm{N}$, they are more efficient at using these nutrients for aboveground growth but then require more of these nutrients for root function. The aboveground demand for $\mathrm{B}, \mathrm{Cu}, \mathrm{Mn}$, and $\mathrm{Zn}$ in PJM and $\mathrm{Mg}, \mathrm{Mn}$, and $\mathrm{Zn}$ in ER was not influenced by $\mathrm{N}$ application although $\mathrm{N}$ application increased root absorption capacity for these nutrients. This suggests the effect of $\mathrm{N}$ application on uptake of these nutrients contributes to luxury consumption and storage and is driven by root demand.

There was no difference in aboveground demand between cultivars for $\mathrm{K}, \mathrm{S}, \mathrm{B}, \mathrm{Cu}$, and $\mathrm{Zn}$ when $\mathrm{N}$ was applied (Table 3 ). If differences between cultivars exist for uptake of these nutrients, the differences do not appear to be a result of aboveground demand. Nitrogenfertilized AZ and ER had lower root absorption capacity and aboveground demand for $\mathrm{Ca}$ and $\mathrm{Mg}$ than PJM. If root absorption capacity is primarily driven by aboveground demand for nutrients, then plants with the lowest nutrient demands would have the lowest root absorption capacity. Thus, root absorption capacity for $\mathrm{Ca}$ and $\mathrm{Mg}$ is strongly linked with aboveground demand. Aboveground growth of PJM may be more sensitive to $\mathrm{Ca}$ and $\mathrm{Mg}$ availability than either ER or AZ. In comparison, $\mathrm{N}$-fertilized ER had higher root absorption capacity and lower aboveground demand for $\mathrm{N}$ than AZ and N-fertilized PJM had higher root absorption capacity and lower aboveground demand for N, P, and Mn than AZ. Therefore, $\mathrm{N}$ limitation in the growing substrate has greater impact on aboveground growth of AZ than ER and N, P, and Mn limitation in the growing substrate has greater impact on aboveground growth of AZ than PJM.

Nutrient use efficiency. Nitrogen application increased the efficiency in which plants used P (AZ), K (PJM), S (PJM, ER, AZ), Ca (PJM, ER, AZ), Mg (PJM, ER, AZ), Cu (PJM, ER), Fe (PJM), and Mn (PJM, ER). This suggests that improved plant $\mathrm{N}$ status may decrease plant requirements for these nutrients. In contrast, $\mathrm{N}$ application decreased the nutrient use efficiency or increased luxury consumption or storage of $\mathrm{N}$ (PJM, ER, AZ), P (PJM), K (AZ), B (PJM, AZ), and Zn (ER). This suggests that improved plant $\mathrm{N}$ status may increase plant requirements for these nutrients. The influence of $\mathrm{N}$ application on plant growth and function did not influence how efficiently plants used P (ER), K (ER), B (ER), Fe (AZ, ER), Mn (AZ), and Zn (PJM, $A Z$ ). This indicates altering $\mathrm{N}$ availability in the growing substrate does not alter a plant's ability to use these nutrients.

There was no difference in B use efficiency between cultivars when $\mathrm{N}$ was applied and no difference in $\mathrm{Fe}$ and $\mathrm{Mn}$ use efficiency between cultivars when $\mathrm{N}$ was limiting to growth (Table 3). Plants of AZ were generally more efficient at using $\mathrm{N}, \mathrm{P}, \mathrm{S}, \mathrm{Mg}$, and Zn than PJM

Table 5. Allocation (percentage of total) of biomass and nutrients to 2005 leaves in Oct. 2005 (Oct), Nov. 2005 (Nov), and Feb. 2006 (Feb) by three cultivars of container-grown Rhododendron grown with $(+N)$ or without $(0 N)$ additional nitrogen $(N)$ fertilizer between May 2005 and Feb. 2006.

\begin{tabular}{|c|c|c|c|c|c|c|c|c|c|c|c|c|c|c|c|c|c|c|c|c|}
\hline \multirow{4}{*}{$\begin{array}{l}\text { Variable } \\
\text { and treatment } \\
\text { Biomass }\end{array}$} & \multicolumn{17}{|c|}{ Cultivar and time (months) ${ }^{\mathrm{z}}$} & & & \\
\hline & \multicolumn{6}{|c|}{$\mathrm{PJM}^{\mathrm{x}}$} & \multicolumn{6}{|c|}{$\mathrm{ER}^{\mathrm{x}}$} & \multicolumn{5}{|c|}{$\mathrm{AZ}^{\mathrm{x}}$} & \multicolumn{3}{|c|}{ Contrasts $^{y}$} \\
\hline & \multicolumn{2}{|c|}{ Oct. } & \multicolumn{2}{|c|}{ Nov. } & \multicolumn{2}{|c|}{ Feb. } & \multicolumn{2}{|c|}{ Oct. } & \multicolumn{2}{|c|}{ Nov. } & \multicolumn{2}{|c|}{ Feb. } & \multicolumn{2}{|c|}{ Oct. } & \multicolumn{2}{|c|}{ Nov. } & \multirow[t]{2}{*}{ Feb. } & \multirow[t]{2}{*}{ PJM } & \multirow[t]{2}{*}{ ER } & \multirow[t]{2}{*}{$\mathrm{AZ}$} \\
\hline & & & & & & & & & & & & & & & & & & & & \\
\hline $0 \mathrm{~N}$ & 16 & $\mathrm{a}$ & 18 & a & 21 & $\mathrm{a}$ & 23 & a & 18 & $\mathrm{a}$ & 24 & $\mathrm{a}$ & 16 & $\mathrm{a}$ & 3 & $\mathrm{a}$ & 0 & NS & NS & $*$ \\
\hline$+\mathrm{N}$ & 23 & $\mathrm{~b}$ & 20 & a & 30 & $\mathrm{~b}$ & 39 & $\mathrm{~b}$ & 33 & $\mathrm{~b}$ & 47 & $\mathrm{~b}$ & 22 & $\mathrm{~b}$ & 18 & $\mathrm{~b}$ & 0 & $L$ & $L$ & NS \\
\hline \multicolumn{21}{|l|}{ Nitrogen } \\
\hline $0 \mathrm{~N}$ & 30 & $\mathrm{a}$ & 33 & a & 35 & $\mathrm{a}$ & 35 & $\mathrm{a}$ & 31 & $\mathrm{a}$ & 36 & $\mathrm{a}$ & 31 & $\mathrm{a}$ & 5 & $\mathrm{a}$ & 0 & NS & NS & $*$ \\
\hline$+\mathrm{N}$ & 38 & $\mathrm{~b}$ & 34 & $\mathrm{a}$ & 44 & $\mathrm{~b}$ & 49 & $\mathrm{~b}$ & 45 & $\mathrm{~b}$ & 59 & $\mathrm{~b}$ & 40 & $\mathrm{~b}$ & 31 & b & 0 & $Q$ & $L$ & $*$ \\
\hline Phosphorus & & & & & & & & & & & & & & & & & & & & \\
\hline $0 \mathrm{~N}$ & 24 & $\mathrm{a}$ & 28 & $\mathrm{a}$ & 29 & $\mathrm{a}$ & 26 & $\mathrm{a}$ & 18 & $\mathrm{a}$ & 23 & $\mathrm{a}$ & 17 & $\mathrm{a}$ & 2 & $\mathrm{a}$ & 0 & $L$ & $Q$ & $*$ \\
\hline$+\mathrm{N}$ & 26 & $\mathrm{a}$ & 26 & a & 33 & $\mathrm{~b}$ & 43 & $b$ & 29 & $\mathrm{~b}$ & 40 & $\mathrm{~b}$ & 18 & $\mathrm{a}$ & 16 & b & 0 & $L$ & $Q$ & NS \\
\hline Potassium & & & & & & & & & & & & & & & & & & & & \\
\hline $0 \mathrm{~N}$ & 38 & $\mathrm{a}$ & 37 & $\mathrm{a}$ & 38 & $\mathrm{a}$ & 36 & $\mathrm{a}$ & 29 & $\mathrm{a}$ & 37 & $\mathrm{a}$ & 41 & $\mathrm{a}$ & 8 & $\mathrm{a}$ & 0 & NS & $Q$ & $*$ \\
\hline$+\mathrm{N}$ & 48 & $\mathrm{~b}$ & 40 & $\mathrm{a}$ & 56 & $\mathrm{~b}$ & 48 & $b$ & 39 & $\mathrm{~b}$ & 55 & $\mathrm{~b}$ & 46 & $\mathrm{a}$ & 52 & b & 0 & $Q$ & $Q$ & NS \\
\hline Sulfur & & & & & & & & & & & & & & & & & & & & \\
\hline $0 \mathrm{~N}$ & 21 & $\mathrm{a}$ & 30 & $\mathrm{a}$ & 23 & $\mathrm{a}$ & 31 & $\mathrm{a}$ & 22 & $\mathrm{e}$ & 22 & $\mathrm{a}$ & 16 & $\mathrm{a}$ & 5 & $\mathrm{a}$ & 0 & $Q$ & $L$ & $*$ \\
\hline$+\mathrm{N}$ & 34 & $\mathrm{~b}$ & 33 & $\mathrm{a}$ & 33 & $\mathrm{~b}$ & 65 & $\mathrm{~b}$ & 35 & $\mathrm{~b}$ & 54 & $\mathrm{~b}$ & 28 & $\mathrm{~b}$ & 19 & b & 0 & NS & $L, Q$ & $*$ \\
\hline Calcium & & & & & & & & & & & & & & & & & & & & \\
\hline $0 \mathrm{~N}$ & 34 & $\mathrm{a}$ & 31 & $\mathrm{a}$ & 33 & $\mathrm{a}$ & 26 & $\mathrm{a}$ & 30 & $\mathrm{a}$ & 36 & $\mathrm{a}$ & 42 & $\mathrm{a}$ & 19 & $\mathrm{a}$ & 0 & NS & $L$ & $*$ \\
\hline$+\mathrm{N}$ & 36 & $\mathrm{a}$ & 27 & $\mathrm{a}$ & 46 & $\mathrm{~b}$ & 43 & $\mathrm{~b}$ & 41 & $\mathrm{~b}$ & 58 & $\mathrm{~b}$ & 46 & $\mathrm{a}$ & 50 & b & 0 & $L, Q$ & $L$ & NS \\
\hline Magnesium & & & & & & & & & & & & & & & & & & & & \\
\hline $0 \mathrm{~N}$ & 29 & $\mathrm{a}$ & 29 & a & 28 & $\mathrm{a}$ & 26 & $\mathrm{a}$ & 26 & $\mathrm{a}$ & 32 & $\mathrm{a}$ & 26 & $\mathrm{a}$ & 10 & $\mathrm{a}$ & 0 & NS & NS & $*$ \\
\hline$+\mathrm{N}$ & 34 & $\mathrm{a}$ & 27 & $\mathrm{a}$ & 40 & b & 45 & $b$ & 44 & $\mathrm{~b}$ & 58 & $\mathrm{~b}$ & 34 & $\mathrm{~b}$ & 34 & b & 0 & $L, Q$ & $L$ & NS \\
\hline Boron & & & & & & & & & & & & & & & & & & & & \\
\hline $0 \mathrm{~N}$ & 43 & $\mathrm{a}$ & 51 & $\mathrm{a}$ & 54 & $\mathrm{a}$ & 51 & $\mathrm{a}$ & 49 & $\mathrm{a}$ & 55 & $\mathrm{a}$ & 48 & $\mathrm{a}$ & 18 & $\mathrm{a}$ & 0 & $L$ & NS & $*$ \\
\hline$+\mathrm{N}$ & 48 & $\mathrm{a}$ & 53 & $\mathrm{a}$ & 57 & $\mathrm{a}$ & 57 & $\mathrm{a}$ & 40 & $\mathrm{a}$ & 54 & $\mathrm{a}$ & 44 & $\mathrm{a}$ & 48 & b & 0 & $L$ & $Q$ & NS \\
\hline Copper & & & & & & & & & & & & & & & & & & & & \\
\hline $0 \mathrm{~N}$ & 4 & $\mathrm{a}$ & 5 & $\mathrm{a}$ & 4 & $\mathrm{a}$ & 8 & $\mathrm{a}$ & 5 & $\mathrm{a}$ & 4 & $\mathrm{a}$ & 4 & $\mathrm{a}$ & 12 & $\mathrm{a}$ & 0 & NS & NS & NS \\
\hline$+\mathrm{N}$ & 7 & $\mathrm{a}$ & 6 & $\mathrm{a}$ & 6 & $\mathrm{a}$ & 29 & b & 13 & $\mathrm{~b}$ & 14 & $\mathrm{~b}$ & 7 & $\mathrm{a}$ & 7 & $\mathrm{a}$ & 0 & NS & $L$ & NS \\
\hline Iron & & & & & & & & & & & & & & & & & & & & \\
\hline $0 \mathrm{~N}$ & 7 & $\mathrm{a}$ & 4 & $\mathrm{a}$ & 4 & $\mathrm{a}$ & 5 & $\mathrm{a}$ & 6 & $\mathrm{a}$ & 7 & $\mathrm{a}$ & 6 & $\mathrm{a}$ & 3 & $\mathrm{a}$ & 0 & NS & NS & NS \\
\hline$+\mathrm{N}$ & 16 & $\mathrm{~b}$ & 8 & $\mathrm{a}$ & 14 & b & 18 & b & 12 & $\mathrm{~b}$ & 17 & b & 7 & $\mathrm{a}$ & 11 & $\mathrm{~b}$ & 0 & $Q$ & $Q$ & NS \\
\hline Manganese & & & & & & & & & & & & & & & & & & & & \\
\hline $0 \mathrm{~N}$ & 37 & $\mathrm{a}$ & 33 & $\mathrm{a}$ & 27 & $\mathrm{a}$ & 22 & $\mathrm{a}$ & 28 & $\mathrm{a}$ & 27 & $\mathrm{a}$ & 31 & $\mathrm{a}$ & 17 & $\mathrm{a}$ & 0 & NS & NS & $*$ \\
\hline$+\mathrm{N}$ & 42 & $\mathrm{a}$ & 30 & $\mathrm{a}$ & 39 & b & 39 & $\mathrm{~b}$ & 41 & $\mathrm{~b}$ & 48 & $\mathrm{~b}$ & 30 & $\mathrm{a}$ & 52 & b & 0 & $Q$ & NS & $*$ \\
\hline Zinc & & & & & & & & & & & & & & & & & & & & \\
\hline $0 \mathrm{~N}$ & 8 & $\mathrm{a}$ & 11 & $\mathrm{a}$ & 8 & $\mathrm{a}$ & 9 & $\mathrm{a}$ & 13 & $\mathrm{a}$ & 19 & $\mathrm{a}$ & 11 & $\mathrm{a}$ & 3 & $\mathrm{a}$ & 0 & NS & $L$ & $*$ \\
\hline$+\mathrm{N}$ & 14 & $\mathrm{~b}$ & 13 & $\mathrm{a}$ & 17 & $\mathrm{~b}$ & 9 & $\mathrm{a}$ & 18 & $\mathrm{~b}$ & 24 & $\mathrm{~b}$ & 12 & $\mathrm{a}$ & 12 & $\mathrm{~b}$ & 0 & NS & $L$ & NS \\
\hline
\end{tabular}

"PJM = Rhododendron 'P.J.M. compact'; ER = Rhododendron 'English Roseum'; and AZ = Rhododendron 'Gibraltar'.

${ }^{y}$ Non-significant (NS) and significant $(P<0.05)$ linear $(L)$ and quadratic $(Q)$ response of allocation between dates for PJM and ER within an N treatment. Non-significant (NS) and significant $(*)$ difference $(P<0.05)$ in allocation between October and November for AZ.

${ }^{\mathrm{x}}$ Values in columns followed by the same lower case letter within a nutrient denote significant $(P<0.05)$ differences in allocation between $\mathrm{N}$ treatments within a cultivar. 
and ER; ER was more efficient at using $\mathrm{Cu}$ than PJM and AZ; and PJM was more efficient at using $\mathrm{K}, \mathrm{Fe}$, and $\mathrm{Mn}$ than ER and $\mathrm{AZ}$. Differences in nutrient use efficiency between cultivars can be used to evaluate the potential effects of cultivar selection on use of production resources. For example, cultivars with greater use efficiency for a certain nutrient are less dependent on these nutrients for growth and production costs related to these nutrients can be optimized.

Allocation to roots. Between Oct. 2005 and Feb. 2006, N-fertilized plants allocated less biomass and nutrients to roots than $\mathrm{N}$-deficient plants (Table 4). Cultivars differed seasonally when $\mathrm{N}$ application influenced biomass and nutrient allocation to roots and these differences were related to differences in locations for nutrient storage and biomass losses during the winter. Decreased biomass allocation to roots in Oct. 2005 and Nov. 2005 in response to $\mathrm{N}$ application coincided with decreased allocation of most nutrients to roots. Nitrogen application decreased allocation of biomass and most nutrients to roots in ER and AZ in Feb. 2006. In contrast, $N$ application had no influence on allocation of biomass and N, P, B, $\mathrm{Cu}$, and $\mathrm{Mn}$ to roots in PJM in February and $\mathrm{N}$ application decreased allocation of $\mathrm{K}, \mathrm{S}, \mathrm{Ca}$, $\mathrm{Mg}$, and $\mathrm{Fe}$ to roots. On average, after maximum biomass was attained, AZ lost $40 \%$ of its total biomass and ER lost $16 \%$ of its total biomass (Table 2). Loss of root biomass accounted for $\approx 30 \%$ and $20 \%$ of total biomass loss in each cultivar, respectively. In contrast, PJM lost $5 \%$ of its total biomass but increased root biomass after maximum biomass was attained. Biomass and nutrient allocation to roots either increased between Oct. 2005 and Feb. 2006 or remained relatively stable in PJM and $\mathrm{AZ}$ and either decreased or remained relatively stable in ER. Plants of PJM and AZ preferentially store nutrients in roots in comparison with ER.

Allocation to leaves. Between Oct. 2005 and Feb. 2006, N-fertilized plants allocated similar or greater biomass to leaves than Ndeficient plants (Tables 4 and 5). Cultivars differed seasonally when $\mathrm{N}$ application influenced biomass and nutrient allocation to leaves and these differences were related to differences in locations for nutrient storage and leaf longevity. Between Oct. 2005 and Nov. 2005, total plant biomass and leaf biomass of AZ remained relatively stable (Table 2; leaf biomass data not shown). Biomass and nutrient allocation to leaves of $\mathrm{N}$-deficient $\mathrm{AZ}$ decreased and biomass allocation to leaves of $\mathrm{N}$-fertilized AZ remained stable but N, S, and $\mathrm{Mn}$ allocation to leaves decreased. Therefore, between October and November, AZ exports many nutrients from leaves before leaf abscission and $\mathrm{N}$ deficiency results in earlier export of nutrients from leaves. Nitrogen deficiency also promoted early nutrient export and abscission of older (2004) leaves on ER and PJM, although the influence of $\mathrm{N}$ availability on nutrient and biomass allocation occurs later in the year compared with PJM. Evergreen cultivars differed in when $\mathrm{N}$ application influenced biomass and nutrient allocation to leaves between Oct. 2005 and Feb. 2006. Biomass and nutrient allocation to leaves in PJM and ER either increased between October and February or remained relatively stable. Higher biomass allocation to leaves in response to $\mathrm{N}$ application coincided with increased allocation of most nutrients to leaves in ER from October to February and increased biomass allocation to leaves in PJM in October and February and not Nov. 2005 or Dec. 2005 (December data not shown). Plants of PJM and ER stored nutrients in leaves over winter and, in general, allocation of nutrients to leaves occurs later in the winter in PJM than in ER.

In fall, PJM generally allocated nutrients mostly to roots and new (2005) leaves, whereas ER allocated nutrients mostly to leaves, and $\mathrm{AZ}$ allocated nutrients mostly to roots. Evergreen and deciduous plants have preferential structures for allocation and storage of nutrients (Kloeppel et al., 2000; Milla et al., 2004; Millard, 1996), and between cultivars of evergreen Rhododendron, there are differences in nutrient storage (Scagel et al., 2007, 2008a, 2008b). Preferential accumulation of reserves in aboveground structures, particularly leaves, has been reported for Rhododendron lapponicum (Jonasson, 1989, 1995).

Allocation to stems. Between Oct. 2005 and Feb. 2006, N-fertilized plants allocated similar or greater biomass to stems than $\mathrm{N}$ deficient plants (Table 7). Cultivars differed seasonally when $\mathrm{N}$ application influenced biomass and nutrient allocation to stems and these differences were related to differences in location and timing of nutrient storage. In general, biomass and nutrient allocation responses by stems to $\mathrm{N}$ application were in older (2004) stems of PJM, newer (2005) stems of ER, and both older and newer stems of AZ (data for different years not shown). Plants of PJM preferentially accumulated $\mathrm{Ca}$, $\mathrm{B}$, and $\mathrm{Mn}$ in stems during the winter and ER preferentially accumulated $\mathrm{K}, \mathrm{S}, \mathrm{B}, \mathrm{Mn}$, and $\mathrm{Zn}$. As discussed, preferential accumulation of some of these nutrients in specific structures may be related to improved cold acclimation and tolerance (Park and Chen, 2006; Raese

Table 6. Allocation (percentage of total) of biomass and nutrients to 2004 leaves in Oct. 2005, Nov. 2005, and Feb. 2006 by three cultivars of container-grown Rhododendron grown with $(+\mathrm{N})$ or without $(0 \mathrm{~N})$ additional nitrogen (N) fertilizer between May 2005 and Feb. 2006.

\begin{tabular}{|c|c|c|c|c|c|c|c|c|c|c|c|c|c|}
\hline \multirow{5}{*}{$\begin{array}{l}\text { Variable and } \\
\mathrm{N} \text { treatment } \\
\text { Biomass } \\
0 \mathrm{~N}\end{array}$} & \multicolumn{11}{|c|}{ Cultivar and time (months) ${ }^{\mathrm{z}}$} & & \\
\hline & \multicolumn{5}{|c|}{$\mathrm{PJM}^{\mathrm{x}}$} & \multicolumn{6}{|c|}{$\mathrm{ER}^{\mathrm{x}}$} & \multicolumn{2}{|c|}{ Contrasts $^{y}$} \\
\hline & \multicolumn{2}{|c|}{ Oct. } & \multicolumn{2}{|c|}{ Nov. } & \multirow[t]{2}{*}{ Feb. } & \multicolumn{2}{|c|}{ Oct. } & \multicolumn{2}{|c|}{ Nov. } & \multicolumn{2}{|c|}{ Feb. } & \multirow[t]{2}{*}{ PJM } & \multirow[t]{2}{*}{ ER } \\
\hline & & & & & & & & & & & & & \\
\hline & 7 & $\mathrm{a}$ & 0 & $\mathrm{a}$ & 0 & 13 & $\mathrm{a}$ & 8 & $\mathrm{a}$ & 10 & $\mathrm{a}$ & $*$ & NS \\
\hline$+\mathrm{N}$ & 12 & a & 11 & $\mathrm{~b}$ & 0 & 21 & $\mathrm{~b}$ & 19 & $\mathrm{~b}$ & 8 & $\mathrm{a}$ & NS & $L$ \\
\hline \multicolumn{14}{|l|}{ Nitrogen } \\
\hline $0 \mathrm{~N}$ & 9 & $\mathrm{a}$ & 0 & $\mathrm{a}$ & 0 & 18 & $\mathrm{a}$ & 12 & $\mathrm{a}$ & 14 & $\mathrm{a}$ & * & NS \\
\hline$+\mathrm{N}$ & 16 & $b$ & 17 & $\mathrm{~b}$ & 0 & 25 & $\mathrm{~b}$ & 25 & $\mathrm{~b}$ & 10 & $\mathrm{a}$ & NS & $L$ \\
\hline \multicolumn{14}{|l|}{ Phosphorus } \\
\hline $0 \mathrm{~N}$ & 7 & $\mathrm{a}$ & 0 & $\mathrm{a}$ & 0 & 16 & $\mathrm{a}$ & 10 & $\mathrm{a}$ & 13 & $\mathrm{a}$ & $*$ & $Q$ \\
\hline$+\mathrm{N}$ & 10 & a & 11 & $\mathrm{~b}$ & 0 & 24 & b & 28 & $\mathrm{~b}$ & 11 & $\mathrm{a}$ & NS & $L$ \\
\hline \multicolumn{14}{|l|}{ Potassium } \\
\hline $0 \mathrm{~N}$ & 16 & $\mathrm{a}$ & 0 & $\mathrm{a}$ & 0 & 21 & $\mathrm{a}$ & 15 & $\mathrm{a}$ & 15 & $\mathrm{a}$ & $*$ & $L$ \\
\hline$+\mathrm{N}$ & 23 & $\mathrm{~b}$ & 24 & $\mathrm{~b}$ & 0 & 27 & $\mathrm{~b}$ & 27 & $\mathrm{~b}$ & 11 & $\mathrm{a}$ & NS & $L$ \\
\hline \multicolumn{14}{|l|}{ Sulfur } \\
\hline $0 \mathrm{~N}$ & 4 & $\mathrm{a}$ & 0 & $\mathrm{a}$ & 0 & 11 & $\mathrm{a}$ & 7 & $\mathrm{a}$ & 12 & $\mathrm{~b}$ & $*$ & NS \\
\hline$+\mathrm{N}$ & 11 & b & 11 & $\mathrm{~b}$ & 0 & 8 & $\mathrm{a}$ & 19 & $\mathrm{~b}$ & 4 & $\mathrm{a}$ & NS & $Q$ \\
\hline \multicolumn{14}{|l|}{ Calcium } \\
\hline $0 \mathrm{~N}$ & 9 & $\mathrm{a}$ & 0 & $\mathrm{a}$ & 0 & 25 & $\mathrm{a}$ & 17 & $\mathrm{a}$ & 22 & $\mathrm{~b}$ & $*$ & $Q$ \\
\hline$+\mathrm{N}$ & 19 & $b$ & 16 & $\mathrm{~b}$ & 0 & 30 & $\mathrm{a}$ & 29 & $\mathrm{~b}$ & 14 & $\mathrm{a}$ & NS & $\widetilde{L}$ \\
\hline \multicolumn{14}{|l|}{ Magnesium } \\
\hline $0 \mathrm{~N}$ & 9 & $\mathrm{a}$ & 0 & $\mathrm{a}$ & 0 & 18 & $\mathrm{a}$ & 12 & $\mathrm{a}$ & 16 & $\mathrm{~b}$ & $*$ & NS \\
\hline$+\mathrm{N}$ & 17 & $\mathrm{~b}$ & 16 & $\mathrm{~b}$ & 0 & 24 & $\mathrm{a}$ & 22 & $\mathrm{~b}$ & 10 & $\mathrm{a}$ & NS & $L$ \\
\hline \multicolumn{14}{|l|}{ Boron } \\
\hline $0 \mathrm{~N}$ & 22 & $\mathrm{a}$ & 0 & $\mathrm{a}$ & 0 & 15 & $\mathrm{a}$ & 13 & $\mathrm{a}$ & 11 & $\mathrm{a}$ & $*$ & NS \\
\hline$+\mathrm{N}$ & 24 & $\mathrm{a}$ & 23 & $\mathrm{~b}$ & 0 & 27 & $\mathrm{~b}$ & 35 & $\mathrm{~b}$ & 15 & $\mathrm{a}$ & NS & $L, Q$ \\
\hline \multicolumn{14}{|l|}{ Copper } \\
\hline $0 \mathrm{~N}$ & 1 & $\mathrm{a}$ & 0 & $\mathrm{a}$ & 0 & 4 & $\mathrm{a}$ & 4 & $\mathrm{a}$ & 2 & $\mathrm{a}$ & $*$ & NS \\
\hline$+\mathrm{N}$ & 4 & a & 4 & $\mathrm{~b}$ & 0 & 17 & $\mathrm{~b}$ & 11 & $\mathrm{~b}$ & 7 & $\mathrm{a}$ & NS & $L, Q$ \\
\hline \multicolumn{14}{|l|}{ Iron } \\
\hline $0 \mathrm{~N}$ & 1 & $\mathrm{a}$ & 0 & $\mathrm{a}$ & 0 & 5 & $\mathrm{a}$ & 9 & $\mathrm{a}$ & 8 & $\mathrm{a}$ & NS & NS \\
\hline$+\mathrm{N}$ & 6 & a & 4 & $\mathrm{~b}$ & 0 & 12 & $\mathrm{~b}$ & 14 & $\mathrm{a}$ & 8 & $\mathrm{a}$ & NS & $L$ \\
\hline \multicolumn{14}{|l|}{ Manganese } \\
\hline $0 \mathrm{~N}$ & 9 & $\mathrm{a}$ & 0 & $\mathrm{a}$ & 0 & 12 & $\mathrm{a}$ & 6 & $\mathrm{a}$ & 7 & $\mathrm{a}$ & $*$ & NS \\
\hline$+\mathrm{N}$ & 18 & b & 17 & b & 0 & 31 & b & 25 & b & 12 & $\mathrm{a}$ & NS & $L$ \\
\hline Zinc & & & & & & & & & & & & & \\
\hline $0 \mathrm{~N}$ & 3 & $\mathrm{a}$ & 0 & $\mathrm{a}$ & 0 & 14 & $\mathrm{a}$ & 9 & a & 12 & b & NS & $Q$ \\
\hline$+\mathrm{N}$ & 9 & $\mathrm{a}$ & 8 & $\mathrm{~b}$ & 0 & 16 & $\mathrm{a}$ & 16 & $\mathrm{~b}$ & 7 & $\mathrm{a}$ & NS & 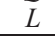 \\
\hline
\end{tabular}

"PJM = Rhododendron 'P.J.M. compact' and ER = Rhododendron 'English Roseum'.

${ }^{y}$ Non-significant (NS) and significant $(P<0.05)$ linear $(L)$ and quadratic $(Q)$ response of allocation between dates for ER within an $\mathrm{N}$ treatment. Non-significant (NS) and significant $(*)$ difference $(P<0.05)$ in allocation between October and November for PJM.

${ }^{\mathrm{x}}$ Values in columns followed by the same lower case letter within a nutrient denote significant $(P<0.05)$ differences in allocation between $\mathrm{N}$ treatments within a cultivar. 
Table 7. Allocation (percentage of total) of biomass and nutrients to stems in Oct. 2005, Nov. 2005, and Feb. 2006 by three cultivars of container-grown Rhododendron grown with $(+\mathrm{N})$ or without $(0 \mathrm{~N})$ additional nitrogen (N) fertilizer between May 2005 and Feb. 2006.

\begin{tabular}{|c|c|c|c|c|c|c|c|c|c|c|c|c|c|c|c|c|c|c|c|c|c|}
\hline \multirow{4}{*}{$\begin{array}{l}\text { Variable and } \\
\mathrm{N} \text { treatment } \\
\text { Biomass }\end{array}$} & \multicolumn{18}{|c|}{ Cultivar and time (months) ${ }^{\mathrm{z}}$} & & & \\
\hline & \multicolumn{6}{|c|}{$\mathrm{PJM}^{\mathrm{x}}$} & \multicolumn{6}{|c|}{$\mathrm{ER}^{\mathrm{x}}$} & \multicolumn{6}{|c|}{$\mathrm{AZ}^{\mathrm{x}}$} & \multicolumn{3}{|c|}{ Contrasts $^{\mathrm{y}}$} \\
\hline & \multicolumn{2}{|c|}{ Oct. } & \multicolumn{2}{|c|}{ Nov. } & \multicolumn{2}{|c|}{ Feb. } & \multicolumn{2}{|c|}{ Oct. } & \multicolumn{2}{|c|}{ Nov. } & \multicolumn{2}{|c|}{ Feb. } & \multicolumn{2}{|c|}{ Oct. } & \multicolumn{2}{|c|}{ Nov. } & \multicolumn{2}{|c|}{ Feb. } & \multirow[t]{2}{*}{ PJM } & \multirow[t]{2}{*}{ ER } & \multirow[t]{2}{*}{$\overline{\mathrm{AZ}}$} \\
\hline & & & & & & & & & & & & & & & & & & & & & \\
\hline $0 \mathrm{~N}$ & 24 & $\mathrm{a}$ & 25 & $\mathrm{a}$ & 29 & a & 16 & $\mathrm{a}$ & 15 & a & 19 & a & 18 & $\mathrm{a}$ & 18 & $\mathrm{a}$ & 20 & a & NS & NS & NS \\
\hline$+\mathrm{N}$ & 36 & $\mathrm{~b}$ & 36 & $\mathrm{~b}$ & 26 & $\mathrm{a}$ & 20 & $\mathrm{a}$ & 22 & b & 23 & $\mathrm{~b}$ & 29 & $\mathrm{~b}$ & 27 & $\mathrm{~b}$ & 34 & $\mathrm{~b}$ & $L$ & NS & $L$ \\
\hline \multicolumn{22}{|l|}{ Nitrogen } \\
\hline $0 \mathrm{~N}$ & 19 & $\mathrm{a}$ & 20 & $\mathrm{a}$ & 25 & a & 10 & $\mathrm{a}$ & 10 & $\mathrm{a}$ & 15 & $\mathrm{a}$ & 18 & $\mathrm{a}$ & 22 & $\mathrm{a}$ & 24 & $\mathrm{a}$ & NS & NS & $L$ \\
\hline$+\mathrm{N}$ & 23 & $\mathrm{a}$ & 24 & $\mathrm{a}$ & 21 & $\mathrm{a}$ & 11 & $\mathrm{a}$ & 12 & $\mathrm{a}$ & 14 & $\mathrm{a}$ & 22 & $\mathrm{a}$ & 27 & b & 37 & b & NS & NS & $L$ \\
\hline Phosphorus & & & & & & & & & & & & & & & & & & & & & \\
\hline $0 \mathrm{~N}$ & 16 & $\mathrm{a}$ & 17 & $\mathrm{a}$ & 22 & $\mathrm{a}$ & 9 & $\mathrm{a}$ & 8 & $\mathrm{a}$ & 11 & $\mathrm{a}$ & 14 & $\mathrm{a}$ & 15 & $\mathrm{a}$ & 17 & $\mathrm{a}$ & NS & NS & NS \\
\hline$+\mathrm{N}$ & 33 & $\mathrm{~b}$ & 32 & b & 24 & $\mathrm{a}$ & 14 & $\mathrm{~b}$ & 19 & b & 19 & b & 26 & $\mathrm{~b}$ & 28 & b & 35 & b & $L$ & NS & $L$ \\
\hline Potassium & & & & & & & & & & & & & & & & & & & & & \\
\hline $0 \mathrm{~N}$ & 16 & $\mathrm{a}$ & 17 & $\mathrm{a}$ & 21 & $\mathrm{a}$ & 9 & $\mathrm{a}$ & 13 & $\mathrm{a}$ & 18 & $\mathrm{a}$ & 21 & $\mathrm{a}$ & 20 & $\mathrm{a}$ & 21 & $\mathrm{a}$ & NS & $L$ & NS \\
\hline$+\mathrm{N}$ & 21 & $\mathrm{a}$ & 20 & $\mathrm{a}$ & 18 & $\mathrm{a}$ & 15 & $\mathrm{~b}$ & 21 & b & 22 & b & 22 & $\mathrm{a}$ & 18 & $\mathrm{a}$ & 36 & $b$ & NS & $L$ & $L$ \\
\hline Sulfur & & & & & & & & & & & & & & & & & & & & & \\
\hline $0 \mathrm{~N}$ & 15 & $\mathrm{a}$ & 18 & $\mathrm{a}$ & 24 & $\mathrm{a}$ & 7 & $\mathrm{a}$ & 9 & $\mathrm{a}$ & 22 & $\mathrm{a}$ & 20 & $\mathrm{a}$ & 19 & $\mathrm{a}$ & 10 & $\mathrm{a}$ & $L$ & $L$ & $L$ \\
\hline$+\mathrm{N}$ & 22 & $\mathrm{~b}$ & 26 & b & 24 & a & 11 & $\mathrm{a}$ & 16 & $\mathrm{a}$ & 18 & $\mathrm{a}$ & 18 & $\mathrm{a}$ & 22 & b & 23 & b & NS & $L$ & NS \\
\hline Calcium & & & & & & & & & & & & & & & & & & & & & \\
\hline $0 \mathrm{~N}$ & 20 & $\mathrm{a}$ & 27 & $\mathrm{a}$ & 33 & $\mathrm{a}$ & 16 & $\mathrm{a}$ & 16 & $\mathrm{a}$ & 18 & $\mathrm{a}$ & 13 & $\mathrm{a}$ & 15 & $\mathrm{a}$ & 26 & $\mathrm{a}$ & $L$ & NS & $L$ \\
\hline$+\mathrm{N}$ & 27 & $\mathrm{~b}$ & 31 & b & 37 & b & 15 & $\mathrm{a}$ & 18 & $\mathrm{a}$ & 16 & $\mathrm{a}$ & 21 & $\mathrm{~b}$ & 20 & b & 49 & $b$ & $L$ & NS & $L$ \\
\hline Magnesium & & & & & & & & & & & & & & & & & & & & & \\
\hline $0 \mathrm{~N}$ & 17 & $\mathrm{a}$ & 12 & $\mathrm{a}$ & 24 & $\mathrm{a}$ & 16 & $\mathrm{a}$ & 16 & $\mathrm{a}$ & 19 & $\mathrm{a}$ & 15 & $\mathrm{a}$ & 16 & $\mathrm{a}$ & 19 & $\mathrm{a}$ & $L$ & NS & NS \\
\hline$+\mathrm{N}$ & 24 & $\mathrm{~b}$ & 23 & $\mathrm{~b}$ & 20 & b & 17 & $\mathrm{a}$ & 18 & a & 17 & a & 23 & $\mathrm{~b}$ & 21 & b & 37 & b & $L$ & NS & $L$ \\
\hline Boron & & & & & & & & & & & & & & & & & & & & & \\
\hline $0 \mathrm{~N}$ & 12 & $\mathrm{a}$ & 12 & $\mathrm{a}$ & 24 & a & 10 & $\mathrm{a}$ & 12 & a & 18 & $\mathrm{a}$ & 14 & $\mathrm{a}$ & 17 & $\mathrm{a}$ & 38 & $\mathrm{a}$ & $L$ & $L$ & $L$ \\
\hline$+\mathrm{N}$ & 16 & $\mathrm{a}$ & 17 & $\mathrm{a}$ & 22 & a & 9 & $\mathrm{a}$ & 15 & $\mathrm{a}$ & 21 & $\mathrm{a}$ & 25 & b & 21 & b & 54 & b & $L$ & $L$ & $L$ \\
\hline Copper & & & & & & & & & & & & & & & & & & & & & \\
\hline $0 \mathrm{~N}$ & 11 & $\mathrm{a}$ & 14 & $\mathrm{a}$ & 13 & $\mathrm{a}$ & 5 & $\mathrm{a}$ & 6 & a & 5 & $\mathrm{a}$ & 10 & $\mathrm{a}$ & 8 & $\mathrm{a}$ & 9 & a & NS & NS & NS \\
\hline$+\mathrm{N}$ & 20 & $\mathrm{~b}$ & 20 & b & 13 & $\mathrm{a}$ & 10 & $\mathrm{~b}$ & 13 & b & 12 & b & 15 & $\mathrm{a}$ & 18 & b & 19 & b & NS & NS & NS \\
\hline Iron & & & & & & & & & & & & & & & & & & & & & \\
\hline $0 \mathrm{~N}$ & 6 & $\mathrm{a}$ & 8 & $\mathrm{a}$ & 8 & $\mathrm{a}$ & 3 & $\mathrm{a}$ & 4 & $\mathrm{a}$ & 4 & $\mathrm{a}$ & 6 & $\mathrm{a}$ & 5 & $\mathrm{a}$ & 6 & $\mathrm{a}$ & NS & NS & NS \\
\hline$+\mathrm{N}$ & 10 & $\mathrm{a}$ & 10 & $\mathrm{a}$ & 7 & $\mathrm{a}$ & 4 & $\mathrm{a}$ & 5 & $\mathrm{a}$ & 6 & $\mathrm{a}$ & 5 & $\mathrm{a}$ & 7 & $\mathrm{a}$ & 15 & b & NS & NS & $L$ \\
\hline Manganese & & & & & & & & & & & & & & & & & & & & & \\
\hline $0 \mathrm{~N}$ & 19 & $\mathrm{a}$ & 30 & $\mathrm{a}$ & 27 & $\mathrm{a}$ & 29 & $\mathrm{~b}$ & 29 & b & 37 & b & 20 & $\mathrm{a}$ & 25 & $\mathrm{a}$ & 38 & $\mathrm{a}$ & $L$ & $L$ & $L$ \\
\hline$+\mathrm{N}$ & 22 & $\mathrm{a}$ & 25 & $\mathrm{a}$ & 31 & $\mathrm{a}$ & 19 & $\mathrm{a}$ & 22 & $\mathrm{a}$ & 26 & $\mathrm{a}$ & 21 & $\mathrm{a}$ & 24 & $\mathrm{a}$ & 59 & b & $L$ & $L$ & $L$ \\
\hline Zinc & & & & & & & & & & & & & & & & & & & & & \\
\hline $0 \mathrm{~N}$ & 10 & $\mathrm{a}$ & 12 & & 14 & $\mathrm{a}$ & 10 & $\mathrm{a}$ & 10 & $\mathrm{a}$ & 15 & $\mathrm{a}$ & 20 & $\mathrm{a}$ & 21 & $\mathrm{a}$ & 26 & $\mathrm{a}$ & NS & $L$ & $L$ \\
\hline$+\mathrm{N}$ & 23 & b & 21 & b & 16 & $\mathrm{a}$ & 9 & $\mathrm{a}$ & 12 & $\mathrm{a}$ & 15 & $\mathrm{a}$ & 28 & b & 29 & b & 47 & b & $L$ & $L$ & $L$ \\
\hline
\end{tabular}

"PJM = Rhododendron 'P.J.M. compact'; ER = Rhododendron 'English Roseum', and AZ = Rhododendron 'Gibraltar'

${ }^{y}$ Non-significant $(\mathrm{NS})$ and significant $(P<0.05)$ linear $(L)$ and quadratic $(Q)$ response of allocation between dates for each cultivar within an $\mathrm{N}$ treatment.

${ }^{\mathrm{y}}$ Values in columns followed by the same lower case letter within a nutrient denote significant $(P<0.05)$ differences in allocation between $\mathrm{N}$ treatments within a cultivar.

and Curry, 2009). Increased biomass allocation to stems of $\mathrm{AZ}$ during winter in response to $\mathrm{N}$ application coincided with increased allocation of most nutrients to stems. These results suggest stems play an important role in storage of most nutrients by $\mathrm{AZ}$ during the winter, similar to the role described for stems of other deciduous plants (Millard, 1996).

Once within the shoot, mobile nutrients (N, P, K) move preferentially to sites of greatest activity or sink strength, as determined by growth form and growth stage, and thus reduced nutrient status is believed to have much less effect on leaves than shoots (Chapin, 1980). Our data do not fully support this hypothesis. Preferential structures for nutrient allocation were less sensitive, more sensitive, or showed similar sensitivity to $\mathrm{N}$ availability than other structures (Tables 5 and 6). For example, PJM preferentially stored nutrients in newer leaves than in older leaves and $\mathrm{N}$ application had less influence on biomass and nutrient accumulation in newer leaves than in older leaves. Low nutrient availability has also been shown to have a greater impact on old leaves than young leaves of the evergreen Rhododendron ferrugineum (Marty et al., 2009). In contrast, ER preferentially stored nutrients in leaves than in stems and roots, and $\mathrm{N}$ application had a similar influence on biomass and nutrient accumulation in most structures. The concept of nutrient status having a smaller impact on large sinks may be common for annual plants; however, in perennial plants in which nutrient storage for the next year is important for plant survival, the influence of nutrient availability on specific structures may also be a reflection of where plants store nutrients.

Biomass and nutrient losses. Nitrogen application increased net biomass and nutrient loss in winter (Table 2). Biomass and nutrient losses in the winter are a result of leaf abscission, stem damage (dieback or abscission), root turnover, and maintenance processes that occur in the winter (Chapin, 1980). Other losses in biomass and nutrients can occur from stresses (e.g., disease, cold damage) and nursery management practices (e.g., pruning and damage from moving or transplanting). Nutrients and biomass were not always equally allocated to the same structures (Tables 4 through 7); therefore, nutrient losses were greater, lesser, or proportional to biomass loss depending on where they were allocated and whether nutrients were exported before biomass loss. Nitrogen application had a pronounced influence on nutrient allocation in roots and these differences influenced nutrient losses during the winter. For example, roots of $\mathrm{N}$-deficient ER contained a higher proportion of $\mathrm{Ca}$ and $\mathrm{Mg}$ than roots of $\mathrm{N}$-fertilized ER; therefore, $\mathrm{N}$ deficient ER lost a greater proportion of total plant $\mathrm{Ca}$ and $\mathrm{Mg}$ as a result of the loss of roots. Similarly N-deficient AZ lost a greater proportion of total plant $\mathrm{Cu}$ than $\mathrm{N}$-fertilized $\mathrm{AZ}$ as a result of the loss of roots, and $\mathrm{N}$-deficient PJM lost a greater proportion of total plant $\mathrm{P}$ and $\mathrm{Cu}$ than $\mathrm{N}$-fertilized PJM as a result of loss of roots.

Biomass and nutrient loss were generally less in PJM than in ER and AZ (Table 2). Plants of N-fertilized ER lost biomass, N, P, K, S, Mg, $\mathrm{B}$, and $\mathrm{Mn}$ at a greater rate than $\mathrm{AZ}$, whereas $\mathrm{AZ}$ lost $\mathrm{Ca}$ and $\mathrm{Zn}$ more rapidly than ER. In comparison, when $\mathrm{N}$-deficient AZ lost biomass at a greater rate than ER and ER lost nutrients at a rate equal to or greater than AZ. Differences in nutrient allocation patterns between cultivars during the winter (Tables 4 through 7) contributed to the magnitude of cultivar differences in nutrient losses. Root loss was a primary contributor to differences in nutrient loss between PJM and ER because ER lost more roots than PJM in winter and PJM preferentially stored more nutrients in roots than ER. In contrast, loss of both leaves and roots were the primary contributors to differences in nutrient loss between PJM and AZ because AZ lost more biomass from leaves and roots than PJM and PJM preferentially stored more nutrients in leaves and less in roots than AZ.

Depending on where plants allocated nutrients (Tables 4 through 7), the relationships between losses of biomass and nutrients in winter can identify whether nutrient losses are a net result of direct biomass loss and/or nutrient export. For example, PJM lost $13 \%$ of its total biomass (mainly from older leaves) in winter and a similar proportion of its total plant $\mathrm{N}$ and allocated more $\mathrm{N}$ to older leaves than biomass; therefore, loss of these nutrients by PJM was a net result of biomass loss and nutrient export from older leaves. Similarly, loss of $\mathrm{N}, \mathrm{Mg}$, and $\mathrm{B}$ by ER and loss of $\mathrm{N}$ by $\mathrm{AZ}$ was a net result of biomass loss and nutrient export from leaves and roots. In contrast, biomass loss occurred without export of $\mathrm{P}, \mathrm{K}, \mathrm{Ca}$, $\mathrm{Mg}, \mathrm{Cu}, \mathrm{Fe}$, and $\mathrm{Zn}$ from older leaves in PJM; $\mathrm{P}, \mathrm{Ca}, \mathrm{Cu}, \mathrm{Fe}, \mathrm{Mn}$, and $\mathrm{Zn}$ from roots and older leaves in $\mathrm{ER}$; and $\mathrm{P}, \mathrm{K}, \mathrm{Ca}, \mathrm{Cu}$, and $\mathrm{Zn}$ from roots and leaves in AZ. These results indicate that resources were not always mobilized from leaves and roots before biomass loss because they have limited mobility in plant tissues, the nutrients in the structures were in excess of plant requirements, or the plant was not able to export nutrients before biomass loss (e.g., rapid damage). The influence of $\mathrm{N}$ availability on allocation of biomass and nutrients to different structures combined with losses of biomass 
from stress, damage, or pruning may have implications to the nutrient reserves that plants require during the next growing season.

Our results indicate $\mathrm{N}$ deficiency 1 ) decreases nutrient uptake and uptake efficiency for nutrients other than N (Tables 1 and 2); 2) alters the timing of nutrient uptake (Table 1); 3 ) decreases root absorption capacity for most nutrients (Table 3); 4) increases allocation of biomass and nutrients to roots (Table 4); 4) decreases allocation of biomass and nutrients to aboveground structures (Tables 5 through 7); and 5) decreases net loss of biomass and nutrients in winter (Table 2). In perennial plants, increased root absorption capacity in response to nutrient deficiency is only a transitory response that cannot be sustained over a long period of time; N-deficient Rhododendron compensated by decreasing aboveground demand to balance the decrease in plant ability to absorb nutrients with growth demands. In our study, this resulted in N-deficient plants having higher nutrient use efficiency for several nutrients than $\mathrm{N}$-fertilized plants.

\section{Literature Cited}

Aerts, R. and F.S. Chapin. 2000. The mineral nutrition of wild plants revisited: A re-evaluation of processes and patterns. Adv. Ecol. Res 30: $1-67$.

Alscher, R.G., N. Erturk, and L.S. Heath. 2002. Role of superoxide dismutases (SODs) in controlling oxidative stress in plants. J. Expt. Bot. 53:1331-1341.

Alt, D. 1998. N-fertilization of nursery crops in the field-A review, part 1. Gartenbauwissen. 63: 165-170.

Bazzaz, F.A. 1997. Allocation of resources in plants: State of the science and critical questions, p. 1-37. In: Bazzaz, F.A. and J. Grace (eds.). Plant resource allocation. Academic Press, San Diego, CA.

Berg, M.G. and E.H. Gardner. 1979. Methods of soil analysis used in the soil testing laboratory at Oregon State University. Oregon State Univ. Agr. Expt. Sta. Spec. Rpt. no. 321.

Bi, G., C.F. Scagel, L.H. Fuchigami, and R.P. Regan. 2007a. Rate of nitrogen application during the growing season alters the response of container-grown rhododendron and azalea to foliar application of urea in the autumn. J. Hort. Sci. Biotechnol. 82:753-763.

Bi, G., C.F. Scagel, L.H. Fuchigami, and R.P. Regan. 2007b. Differences in growth and nitrogen uptake and storage between two container-grown cultivars of Rhododendron. J. Environ. Hort. 25:13-20.

Cabrera, R.I. 2004. Nitrogen balance for two container-grown woody ornamental plants. Sci. Hort. 97:297-308.

Chapin, F.S., III, 1980. The mineral nutrition of wild plants. Annu. Rev. Ecol. Syst. 11:233-260.

Chapin, F.S., III, A.J. Bloom, C.B. Field, and R.H. Waring. 1987. Plant responses to multiple environmental factors. BioSci. 37:49-57.

Chapin, F.S., III, E. Schulze, and H.A. Mooney. 1990. The ecology and economics of storage in plants. Annu. Rev. Ecol. Syst. 21:423-447.
Colangelo, D.J. and M.H. Brand. 2001. Nitrate leaching beneath a containerized nursery crop receiving trickle or overhead irrigation. J. Environ. Qual. 30:1564-1574.

Epstein, E. and A.J. Bloom. 2005. Mineral nutrition of plants: Principles and perspectives. 2nd Ed. Sinauer Associates, Sunderland, MA.

Grelet, G., I.J. Alexander, and M.F. Proe. 2001. Leaf habit influences nitrogen remobilization in Vaccinium species. J. Expt. Bot. 52:993-1002.

Grelet, G.A., I.J. Alexander, P. Millard, and M.F. Proe. 2003. Does morphology or the size of the internal $\mathrm{N}$ store determine how Vaccinium $\mathrm{spp}$ respond to spring $\mathrm{N}$ supply? Funct. Ecol. 17: 690-699.

Guthrie, W., J. Filliben, and A. Heckert. 2005. Process modeling. In: NIST/SEMATECH e-handbook of statistical methods. National Institute of Standards and Technology. 28 Dec. 2010. <http:// www.itl.nist.gov/div898/handbook/>.

Huett, D.O. 1997. Fertiliser use efficiency by containerized nursery plants, 2 . Nutrient leaching. Aust. J. Agr. Res. 48:259-265.

Ingestad, T. 1991. The influence of plant nutrition on biomass allocation. Ecol. Appl. 1:168-174.

Jonasson, S. 1989. Implications of leaf longevity, leaf nutrient re-absorption and translocation for the resource economy of five evergreen plant species. Oikos 56:121-131.

Jonasson, S. 1995. Growth and nutrient allocation in relation to leaf retention time of the wintergreen Rhododendron lapponicum. Ecol. 76:475-485.

Karlsson, P.S. 1994. The significance of internal nutrient cycling in branches for growth and reproduction of Rhododendron lapponicum. Oikos 70:191-200.

Kloeppel, B.D., S.T. Gower, J.G. Vogel, and P.B. Reich. 2000. Leaf-level resource use for evergreen and deciduous conifers along a resource availability gradient. Funct. Ecol. 14:281-292.

Kummerow, J. 1983. Comparative phenology of Mediterranean-type plant communities, $p$ 300-317. In: Kruger, F.J., D.T. Mitchell, and J.U.M. Jarvis, (eds.). Mediterranean-type ecosystems. The role of nutrients. Springer-Verlag, Heidelberg, Germany.

Lamaze, T., F. Pasche, and A. Pornon. 2003. Uncoupling nitrogen requirements for spring growth from root uptake in a young evergreen shrub (Rhododendron ferrugineum). New Phytol. 159:637-644.

Marschner, H. 1995. Mineral nutrition of higher plants. 2nd Ed. Academic Press, San Diego, CA.

Marty, C., T. Lamaze, and A. Pornon. 2009 Endogenous sink-source interactions and soil nitrogen regulate leaf life-span in an evergreen shrub. New Phytol. 183:1114-1123.

Méndez, M. and P.S. Karlsson. 2004. Nutrient stoichiometry in Pinguicula vulgaris: Nutrient availability, plant size, and reproductive status. Ecol. 86:982-991.

Milla, R., P. Castro-Díaz, M. Maestro-Martínez, and G. Montserrat-Martií. 2005. Environmental constraints on phenology and internal nutrient cycling in the Mediterranean winter-deciduous shrub Amelanchier ovalis Medicus. Plant Biol. (Stutt) 7:182-189.

Milla, R., M. Maestro-Martíez, and G. MontserratMartí. 2004. Seasonal branch nutrient dynamics in two Mediterranean woody shrubs with contrasted phenology. Ann. Bot. (Lond.) 93:671-680.
Millard, P. 1996. Ecophysiology of the internal cycling of nitrogen for tree growth. J. Plant Nutr. Soil Sci. 159:1-10.

Miyazawa, Y. and K. Kikuzawa. 2005. Winter photosynthesis by saplings of evergreen broad-leaved trees in a deciduous temperature forest. New Phytol. 165:857-866.

Ohlson, M. and H. Staaland. 2001. Mineral diversity in wild plants: Benefits and bane for moose. Oikos 94:442-454.

Park, E.J. and T.H.H. Chen. 2006. Improvement of cold tolerance in horticultural crops by genetic engineering. J. Crop Improv. 17:69-120.

Pasche, F., A. Pornon, and T. Lamaze. 2002. Do mature leaves provide a net source of nitrogen supporting shoot growth in Rhododendron ferrugineum? New Phytol. 154:99-105.

Piepho, H.P. and J.O. Ogutu. 2003. Inference for the break point in segmented regression with application to longitudinal data. Biometrical J. 45:591-601.

Raese, T. and E.A. Curry. 2009. Bioregulators influence calcium concentration and cold hardiness of young 'Delicious' (Malus Domestica, Borkh) apple trees. J. Plant Nutr. 33:1-9.

Ristvey, A.G., J.D. Lea-Cox, and D.S. Ross. 2004. Nutrient uptake, partitioning and leaching losses from container-nursery production systems. Acta Hort. 630:321-328.

Rodgers, C.O. and A.J. Barneix. 2006. Cultivar differences in the rate of nitrate uptake by intact wheat plants as related to growth rate. Physiol. Plant. 72:121-126.

Rytter, L., T. Ericsson, and R.M. Rytter. 2003. Effects of demand-driven fertilization on nutrient use, root:plant ratio and field performance of Betula pendula and Picea abies. Scand. J. For. Res. 18:401-415.

Scagel, C.F., G. Bi, L.H. Fuchigami, and R.P. Regan. 2007. Season variation in growth, nitrogen uptake and allocation by containergrown evergreen and deciduous Rhododendron cultivars. HortScience 42:1440-1449.

Scagel, C.F., G. Bi, L.H. Fuchigami, and R.P. Regan. 2008a. Nitrogen availability alters mineral nutrient uptake and demand in containergrown deciduous and evergreen Rhododendron. J. Environ. Hort. 26:177-187.

Scagel, C.F., G. Bi, L.H. Fuchigami, and R.P. Regan. 2008b. Rate of nitrogen application during the growing season and spraying plants with urea in the autumn alters uptake of other nutrients by deciduous and evergreen container-grown Rhododendron cultivars. HortScience 43:1569-1579.

Schabenberger, O. and F.J. Pierce. 2002. Contemporary statistical models for the plant and soil sciences. CRC Press, Boca Raton, FL.

Shuai, X., Z. Zhou, and R.S. Yost. 2003. Using segmented regression models to fit soil nutrient and soybean grain yield changes due to liming. J. Agr. Biol. Environ. Stat. 8:240-252.

Struve, D.K. and M.A. Rose. 1998. Early-season fertilization reduces fertilizer use without reducing plant growth. J. Environ. Hort. 16:4751.

Toms, J.D. and M.L. Lesperance. 2003. Piece-wise regression: A tool for identifying ecological thresholds. Ecol. 84:2034-2041.

Witt, H.H. 1994. Regulation of nitrogen supply of Rhododendron hybrids. Acta Hort. 364:79-87. 